\title{
Projecting Relative Sea Level Rise under Climate Change at the Phrachula Chomklao Fort Tide Gauge in the Upper Gulf of Thailand
}

\author{
Chirayu Jaroenongard ${ }^{1}$, Mukand S. Babel ${ }^{1, *}$, Sangam Shrestha ${ }^{1}$, Sutat Weesakul ${ }^{2}$, Vilas Nitivattananon ${ }^{3}$ and \\ Dibesh Khadka ${ }^{1}$
}

1 Water Engineering and Management, Asian Institute of Technology, P.O. Box 4, Klong Luang, Pathumthani 12120, Thailand; st115744@ait.ac.th (C.J.); sangam@ait.ac.th (S.S.); dibesh.khadka@ait.asia (D.K.)

2 Hydro Informatics Institute, 901 Lat Yao, Chatuchak, Bangkok 10900, Thailand; sutat@hii.or.th

3 Urban Environmental Management, Asian Institute of Technology, P.O. Box 4, Klong Luang, Pathumthani 12120, Thailand; vilasn@ait.ac.th

* Correspondence: msbabel@ait.ac.th; Tel.: +66-86-089-8949

check for updates

Citation: Jaroenongard, C.; Babel, M.S.; Shrestha, S.; Weesakul, S.; Nitivattananon, V.; Khadka, D. Projecting Relative Sea Level Rise under Climate Change at the Phrachula Chomklao Fort Tide Gauge in the Upper Gulf of Thailand. Water 2021, 13, 1702. https://doi.org/ 10.3390/w13121702

Academic Editor: Xing Fang

Received: 8 May 2021

Accepted: 16 June 2021

Published: 19 June 2021

Publisher's Note: MDPI stays neutral with regard to jurisdictional claims in published maps and institutional affiliations.

Copyright: (C) 2021 by the authors. Licensee MDPI, Basel, Switzerland. This article is an open access article distributed under the terms and conditions of the Creative Commons Attribution (CC BY) license (https:/ / creativecommons.org/licenses/by/ $4.0 /)$.

\begin{abstract}
This study aims to project future sea-level rise (SLR) at the Phrachula Chomklao Fort (PCF) tide gauge station in the Upper Gulf of Thailand (UGoT) using the outputs of 35 climate models under two greenhouse gas concentration scenarios: representative concentration pathway 4.5 (RCP4.5) and RCP8.5. The Linear Scaling method was found to be better than Variance Scaling and Quantile Mapping methods for removing biases in raw Global Circulation Models (GCMs) sea level data. Land subsidence, induced by excessive groundwater abstraction, was found to contribute significantly to SLR during the observed period the PCF gauging station; hence, the effects of land subsidence had to be removed from relative sea level before bias correction. The overall increase in SLR is projected to be $0.94-1.05 \mathrm{~mm}$ /year under RCP4.5 and 1.07-1.18 mm/year under RCP8.5 for the twenty-first century in the UGoT. The results suggest that future SLR due to climate change will not be as severe in the study region compared to average global projections. However, land subsidence can amplify future SLR. It is therefore important to regulate groundwater abstraction in the future so that SLR can be restricted. It is even more relevant in the UGoT as the raw water intake from the Chao Phraya River for municipal water supply to Bangkok is close to the estuary, and SLR in the future can pose additional challenges for the water utility.
\end{abstract}

Keywords: climate change; bias correction; sea level rise; land subsidence; coastal countries; Gulf of Thailand

\section{Introduction}

According to a report by the Intergovernmental Panel on Climate Change (IPCC) [1], the global mean (land and ocean surface combined) temperature has increased by approximately $1{ }^{\circ} \mathrm{C}\left(0.8^{\circ} \mathrm{C}-1.0^{\circ} \mathrm{C}\right)$ since pre-industrial levels, and the increase is expected to be $1.5^{\circ} \mathrm{C}$ by $2030-2052$. The thermal expansion of seawater and melting glaciers and ice sheets due to the temperature increase have led to a rise in global mean sea levels since the early 1970s [2]. The rate of the global mean SLR (with a likelihood of 90-100\%) was $1.7 \mathrm{~mm} /$ year from 1901 to 2010, resulting in a total SLR of $0.19 \mathrm{~m}$. However, the rate of SLR was higher (3.2 [2.8 to 3.6] mm/year) during the recent period, from 1993 to 2010 [3], and this rate is likely to increase with increasing temperature in the next few decades [4]. The observed global mean SLR of $3.2 \mathrm{~mm}$ /year during 1993-2010 is primarily due to ocean thermal expansion and changes in glaciers, the Greenland ice sheet, the Antarctic ice sheet, and land water storage at an estimated $1.10,0.76,0.33,0.27$, and $0.38 \mathrm{~mm}$ /year, respectively [2]. The continued increase in ocean warming and loss of mass from glaciers and ice sheets 
under all the Representative Concentration Pathways (RCPs) supports the understanding that the sea level will continue to rise at rates higher than it did in the past.

Global SLR causes storm surges, erosion and degradation, and saltwater intrusion into coastal regions. SLR affects tidal currents in many estuaries [5], leading to increased salinity in both surface water and groundwater systems. This may threaten domestic and agricultural water supply in coastal areas like the Apalachicola River in the USA, the Gorai River in Bangladesh, the Puzih River in Taiwan, and the Chao Phraya River in Thailand [6-9].

Excessive groundwater pumping in coastal areas may also lead to land subsidence, thereby increasing the threat of seawater intrusion into groundwater systems. Most coastal aquifers are quite vulnerable to excessive groundwater abstraction [10]. The combined effects of SLR and land subsidence, mainly driven by excessive groundwater abstraction at the local level, may exacerbate SLR in several coastal regions [9]. A study by Liu et al. (2020) [11] at a tide gauging station in Texas found that land subsidence driven by aquifersystem compaction due to groundwater extraction has contributed about $85 \%$ of the total relative sea-level rise (of $0.7 \mathrm{~m}$ ) since 1909 and will continue to play a significant role in SLR further into the twenty-first century. Saramul and Ezer (2014) [12] investigated the historical rate of SLR in the Gulf of Thailand and the Andaman sea and found that the rate of SLR varies from $\sim 1 \mathrm{~mm} /$ year to $\sim 20 \mathrm{~mm} /$ year. The study also found that the maximum rate of SLR was in the Upper Gulf of Thailand (UGoT) near Bangkok, where land subsidence is mainly dominated by groundwater abstraction. Yet, another contributing factor to SLR is changes in vertical land motion driven by earthquakes. For example, the Sumatra-Andaman Earthquake of 2004 accelerated SLR in the Gulf of Thailand and the Andaman Sea [12].

Seawater intrusion endangers the availability of freshwater for human consumption and economic activities in coastal regions; hence, it becomes necessary to understand what changes will take place in SLR in the future under changing climatic conditions. Church and White (2006), Nerem et al. (2018), and Slangen et al. (2014) [3,13,14] have attempted to project changes in SLR based on various climate change scenarios at global, regional, and local levels. However, these studies have projected future sea levels without considering biases in GCM data. It is important to remove biases inherent in climate models to improve projections. The authors of the present study could not find any previous studies which have considered removing biases present in raw GCM sea level for future SLR projections. In addition to climate-change-driven SLR, changing local-level anthropogenic factors and the social and environmental drivers of those factors may also influence relative SLR (i.e., the dual impact of SLR and coastal land subsidence) [15].

Bangkok, the capital city of Thailand, lies within the coastal region of the Upper Gulf of Thailand (UGoT). Bangkok's population of over 8 million is dependent on the Chao Phraya River for its freshwater supply. The river flows from the northern part of Thailand, passes through the city, and drains into the sea at the Gulf of Thailand in the Samut Prakan Province. Over the last several decades, many industries have been established in Bangkok and its surrounding provinces—mainly Nonthaburi and Samut Prakan —as an effort towards industrial development for rapid economic growth by the government. Consequently, the demand for water, especially by industries, has also increased. Groundwater in Bangkok is of good quality and quantity. However, excessive groundwater pumping in Bangkok and the surrounding areas, which went up to $2.2 \mathrm{Mm}^{3} / \mathrm{d}$ in 1999 [16], has caused land subsidence for more than half a century. In the early 1980s, the land subsidence rate was more than $120 \mathrm{~mm} /$ year; it reduced to $10 \mathrm{~mm} /$ year in the 2000s [9]. Groundwaterextraction-induced land subsidence has emerged as a serious issue not only in Bangkok but also in the Mekong delta [17]. By investigating long-term tidal data and short-term altimetry measurements in the Gulf of Thailand, Trisirisatayawong et al. (2011) [18] found that relative sea level is rising significantly faster than global average rates and land subsidence due to excessive groundwater extraction, and earthquakes were the major contributors to it [12]. 
Saltwater intrusion driven by land subsidence and SLR has been threatening the quality of raw water abstracted by the MWA from Chao Phraya for municipal water supply. The raw water intake by MWA for freshwater supply for Bangkok and its surrounding provinces lies in the Samlae District in the Pathum Thani Province (around $96 \mathrm{~km}$ from the Chao Phraya's mouth). In 2015, for example, Bangkok faced a serious salinity problem in its raw water for the municipal water supply. An increase in agricultural water use upstream of the Chao Phraya River caused low river flows at the point of abstraction. At the same time, high tide and associated SLR caused seawater intrusion in the downstream portion of the river. This resulted in extremely high levels of salinity in raw water at the Samlae raw water pumping station. As a mitigation measure, the agency has even been considering shifting the raw water pumping location further upstream (as per personal communication with MWA officials).

SLR is expected to have catastrophic effects on the coastal population. Estimates based on the coastal Digital Elevation Model (DEM) reveal that even under the low-emission scenario of RCP2.6, coastal land, which is home to $17 \%$ of the world's population, will be below the high tidal line by 2100 [19]. In this context, it is imperative to understand the impacts of climate change on SLR, which will affect saltwater intrusion in the Chao Phraya River and ultimately the quality and quantity of water that can be extracted for different water uses in the future. The present study aimed at projecting future sea level at the Phrachula Chomklao Fort (PCF) tide gauge station in the UGoT, which is at the Chao Phraya River mouth, considering two important drivers: climate change and land subsidence. Three future periods-near-future (2021-2050); mid-future (2051-2080); and farfuture (2081-2100) - were considered for the sea-level projections along with the long-term (2021-2100) trends. The study has compared three bias correction methods for removing systematic errors in sea-level data from the climate models. In addition, to quantify the uncertainties associated with climate models due to an imperfect representation of physics of atmospheric/oceanic processes in the models, we considered a large set of climate models from the fifth phase of the Coupled Model Intercomparison Project (CMIP5) to provide a plausible range of future projections. The results of the study will be useful to understand the impacts of projected SLR at the local level as well as its consequences in terms of raw water quality at the intake point for Bangkok's municipal water supply; it will also help in determining the remedial measures required to meet municipal water demands in the future.

\section{Materials and Methods}

\subsection{Study Area}

Thailand is in the middle of the Southeast Asia region; it is located at $5^{\circ} 37^{\prime}$ to $20^{\circ} 28^{\prime}$ $\mathrm{N}$ and $97^{\circ} 21^{\prime}$ to $105^{\circ} 38^{\prime} \mathrm{E}$. It is surrounded by Myanmar in the West, Cambodia in the South-East, Laos in the North-East, and Malaysia in the South. The Gulf of Thailand's (GoT) boundary stretches from the Thai-Malay border to the cape of Ca Mau in Vietnam and opens into the South China Sea in the southeastern part [20]. The Chao Phraya River, the main lifeline of the country, and the Tha Chin, Mae Klong and Bang Pakong Rivers drain into the Gulf of Thailand, as shown in Figure 1. The Upper Gulf of Thailand (UGoT) is a semi-enclosed shallow sea, approximately $100 \mathrm{~km} \times 100 \mathrm{~km}$, and refers to the area above the line between Hua Hin and Ko Samaesarn (Figure 1). It lies approximately between $12^{\circ} 30^{\prime} \mathrm{N}$ and $13^{\circ} 30^{\prime} \mathrm{N}$ and between $100^{\circ} 00^{\prime} \mathrm{E}$ and $101^{\circ} 00^{\prime} \mathrm{E}$ and is surrounded by land on the eastern, northern, and western sides, and the GoT to the south [21,22]. Eight sea level measuring stations, as shown in Figure 1, are located in the UGoT. Figure 2 presents the period of data availability at these stations. For most of the stations, data are available after 1980, while the longest data availability period is observed at PCF and Ko Sichang (KS). 


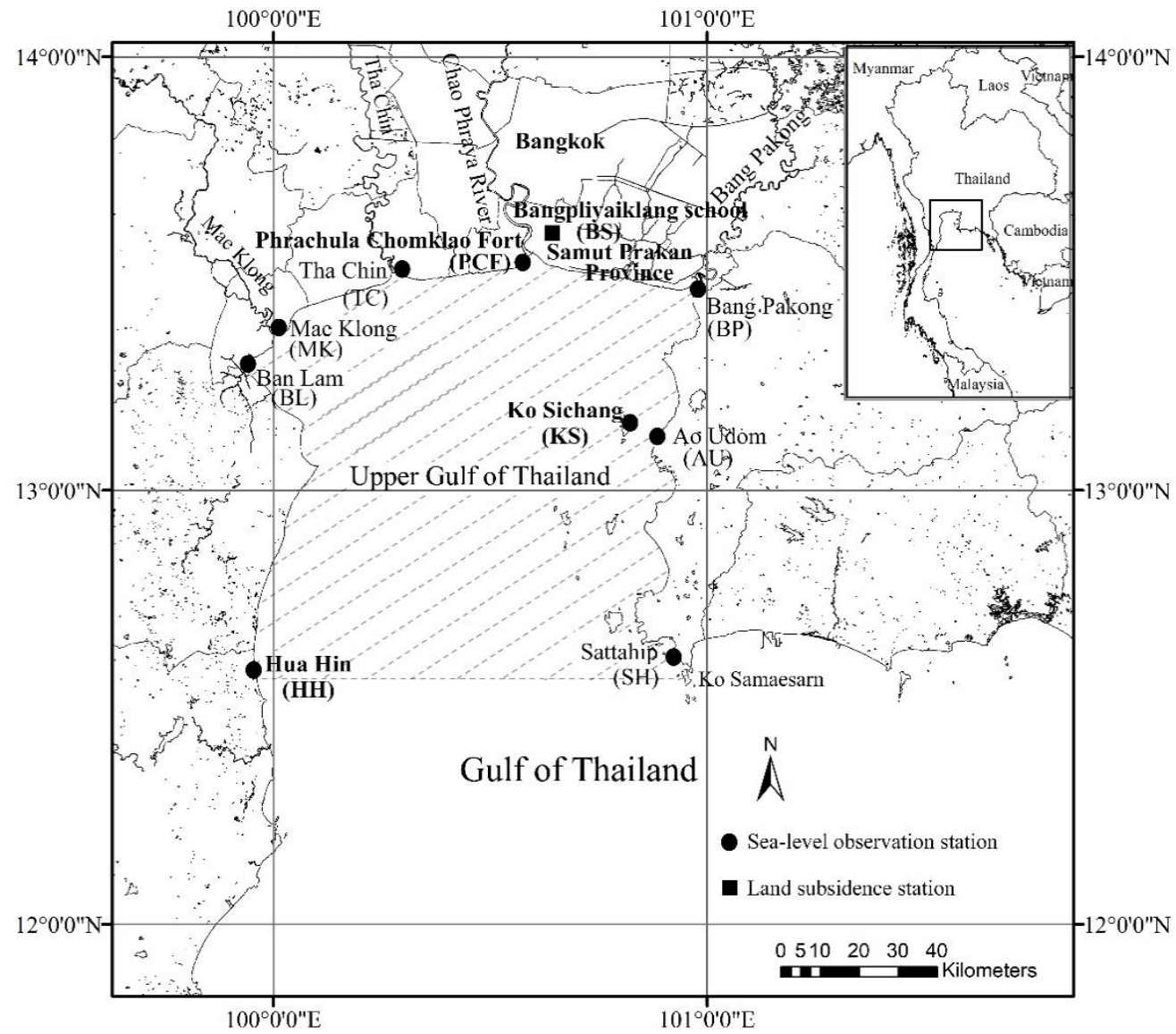

Figure 1. Study area and the sea-level monitoring stations in the UGoT.

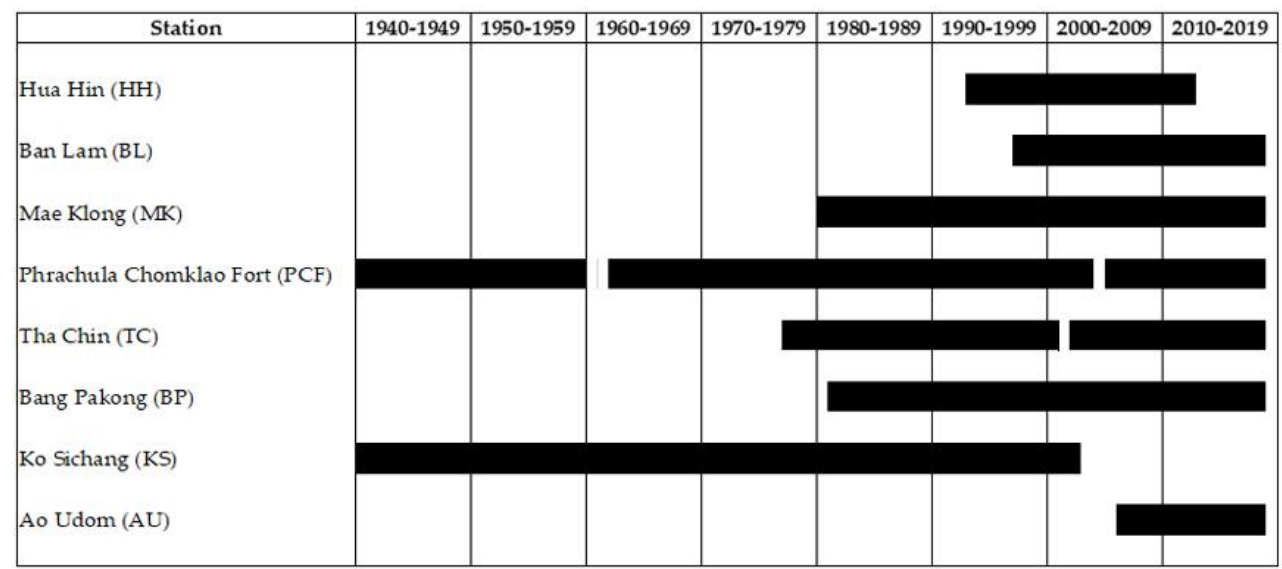

Figure 2. Data availability period for the sea-level observation stations in the UGoT.

\subsection{Data}

The data required for the study consisted of (i) observed relative sea-level data at eight stations in UGoT, (ii) groundwater pumping and land-subsidence data in the Samut Prakan province, and (iii) historical and future sea levels, as projected by Global Circulation Models (GCMs). Table 1 presents the details of the observed data used in the study. The monthly sea-level data at the PCF and KS stations were obtained from the Permanent Service for Mean Sea Level (PSMSL), at Hua Hin (HH) from the Hydrographic Department of the Royal Thai Navy, Thailand, and at Ban Lam (BL), Mae Klong (MK), Tha Chin (TC), Bang Pakong (BP), and Ao Udom (AU) from the Marine Department, Thailand. Land subsidence data at Bangpliyaiklang School (BS), which is about $15 \mathrm{~km}$ from the PCF station, 
and groundwater pumping data in the Samut Prakan province were obtained from the Department of Groundwater Resources (DGR) of Thailand. Figure 3 indicates the observed monthly (relative) SLR at eight stations in the UGoT. Significant increasing trends of relative SLR (14.4-18.5 mm/year) are observed at PCF, MK, and TC stations which are located within or near the Bangkok Metropolitan area. The rates of relative SLR at BP, and BL stations, which are further away from the area of interest, are smaller (4.8 and $6.7 \mathrm{~mm} /$ year, respectively). The least trends of relative SLR are observed at $\mathrm{HH}$ and KS stations ( 0.48 and $0.72 \mathrm{~mm} /$ year, respectively). The data availability at BL and AU are too short for climate change analyses, while the stations at MK, TC are highly affected by land subsidence [12]. As seen from Figure 3, the trends of relative SLR at PCF, TC, and BP after 2003, when the KS station does not have data, are found to be 5.1, 10.5, and $7.3 \mathrm{~mm} /$ year. It shows that all of these three stations are most likely affected by land subsidence; hence, the sea level records at TC and BP cannot be directly used to estimate absolute SLR at the PCF station. Therefore, the PCF, HH, and KS stations are considered in the study. The increase in sea level at PCF will potentially affect salinity intrusion in the Chao Phraya River and ultimately affect the water quality and quantity abstracted by the MWA for its service area covering Bangkok, Nonthaburi, and Samut Prakan. HH and KS are situated in the eastern and western sides of the UGoT, respectively, and hence are useful in estimating the average changes in the sea level in the region. Unlike PCF, the latter two stations are not affected by land subsidence, as described later in the article. Among the selected stations, it was seen that the monthly sea level data at the PCF station has a significant increasing trend, which has become especially pronounced after 1960, while no such substantial trends in sea level were observed at KS and HH (Figure 4). These two stations (KS and HH) depict only slightly increasing trends in sea level.

Table 1. Details of observed data used in the study.

\begin{tabular}{|c|c|c|c|c|c|}
\hline \multirow{2}{*}{ Data/Station } & \multicolumn{2}{|c|}{ Location } & \multirow{2}{*}{ Frequency } & \multirow{2}{*}{ Data Period } & \multirow{2}{*}{ Remarks } \\
\hline & Lat & Long & & & \\
\hline \multicolumn{6}{|l|}{ Sea level } \\
\hline Hua Hin $(\mathrm{HH})$ & $12^{\circ} 34^{\prime} 22^{\prime \prime} \mathrm{N}$ & $99^{\circ} 57^{\prime} 48^{\prime \prime} \mathrm{E}$ & Monthly & 1992-2012 & \multirow{8}{*}{$\begin{array}{l}\text { Data missing for } 1960, \\
1961 \text { and } 2004 \\
\text { Data missing for } 2001\end{array}$} \\
\hline Ban Lam (BL) & $13^{\circ} 15^{\prime} 47^{\prime \prime} \mathrm{N}$ & $99^{\circ} 56^{\prime} 44^{\prime \prime} \mathrm{E}$ & Monthly & $1997-2018$ & \\
\hline Mae Klong (MK) & $13^{\circ} 22^{\prime} 36^{\prime \prime} \mathrm{N}$ & $99^{\circ} 59^{\prime} 44^{\prime \prime} \mathrm{E}$ & Monthly & 1980-2018 & \\
\hline $\begin{array}{c}\text { Phrachula Chomklao } \\
\text { Fort (PCF) }\end{array}$ & $13^{\circ} 33^{\prime} 06^{\prime \prime} \mathrm{N}$ & $100^{\circ} 34^{\prime} 44^{\prime \prime} \mathrm{E}$ & Monthly & 1940-2018 & \\
\hline Tha Chin (TC) & $13^{\circ} 30^{\prime} 36^{\prime \prime} \mathrm{N}$ & $100^{\circ} 16^{\prime} 40^{\prime \prime} \mathrm{E}$ & Monthly & 1977-2018 & \\
\hline Bang Pakong (BP) & $13^{\circ} 29^{\prime} 00^{\prime \prime} \mathrm{N}$ & $101^{\circ} 00^{\prime} 23^{\prime \prime} \mathrm{E}$ & Monthly & 1981-2018 & \\
\hline Ko Sichang (KS) & $13^{\circ} 09^{\prime} 00^{\prime \prime} \mathrm{N}$ & $100^{\circ} 49^{\prime} 00^{\prime \prime} \mathrm{E}$ & Monthly & 1940-2002 & \\
\hline Ao Udom (AU) & $13^{\circ} 07^{\prime} 25^{\prime \prime} \mathrm{N}$ & $100^{\circ} 53^{\prime} 46^{\prime \prime} \mathrm{E}$ & Monthly & 2006-2018 & \\
\hline Land subsidence & & & & & \\
\hline $\begin{array}{l}\text { Bangpliyaiklang } \\
\text { School (BS) }\end{array}$ & $13^{\circ} 36^{\prime} 27^{\prime \prime} \mathrm{N}$ & $100^{\circ} 42^{\prime} 12^{\prime \prime} \mathrm{E}$ & Annual & 1987-2016 & $\begin{array}{c}\text { Data missing for } 1999, \\
2013, \text { and } 2015\end{array}$ \\
\hline $\begin{array}{l}\text { Groundwater } \\
\text { pumping }\end{array}$ & \multicolumn{2}{|c|}{ Samut Prakan province } & Annual & $\begin{array}{l}\text { 1996-2006; } \\
\text { 2012-2016 }\end{array}$ & \\
\hline
\end{tabular}




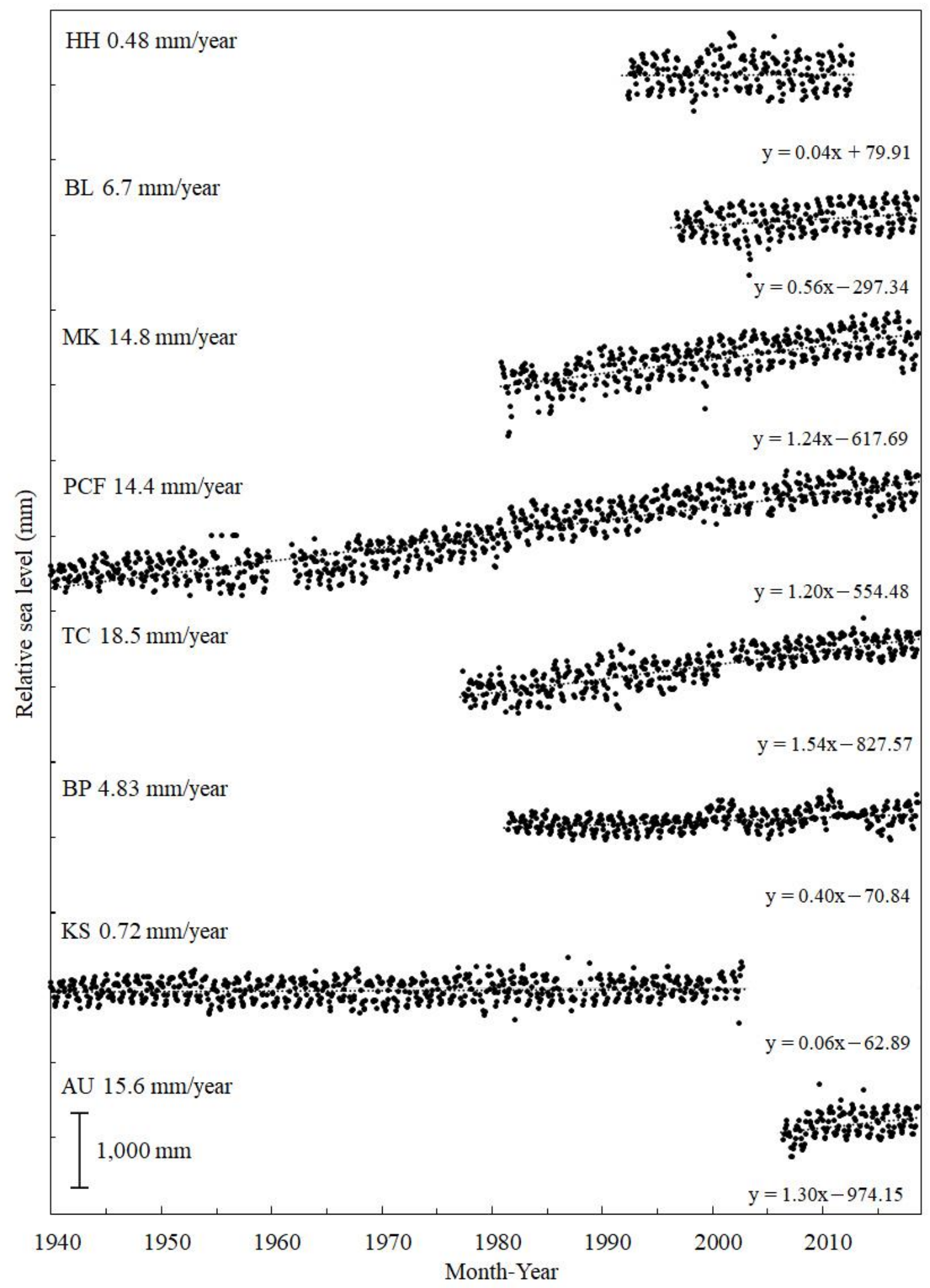

Figure 3. Observed monthly (relative) sea levels at eight stations in the UGoT. The linear trend is shown by the dotted line and the rate of (relative) sea level rise is shown in $\mathrm{mm} /$ year at each station. 


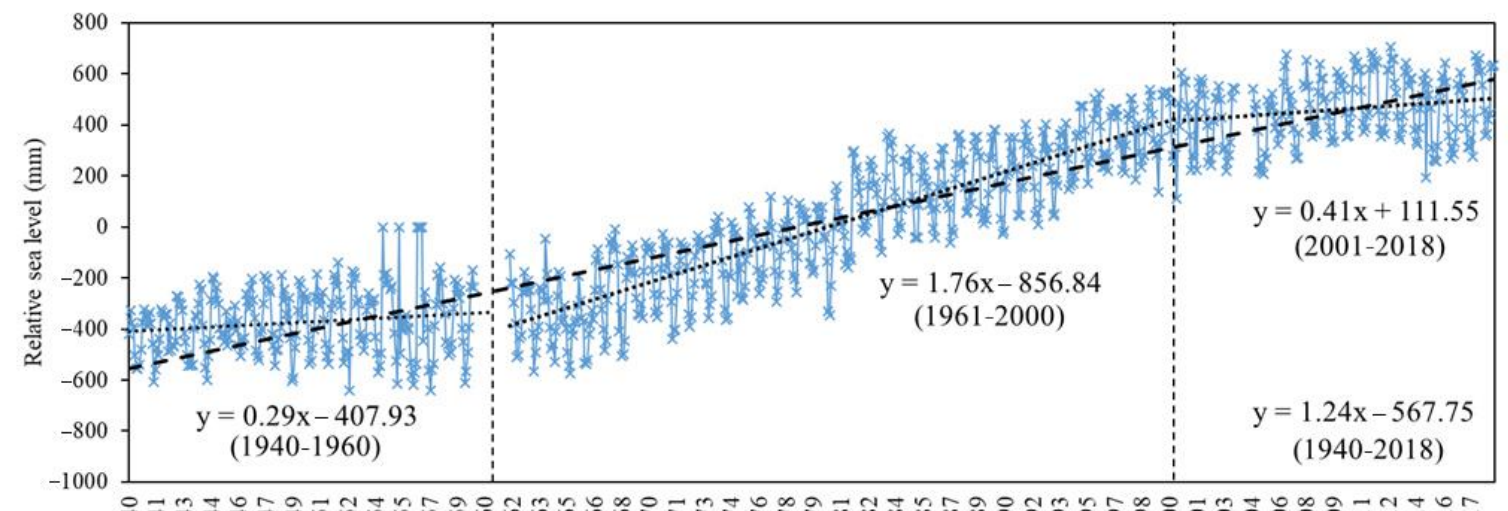

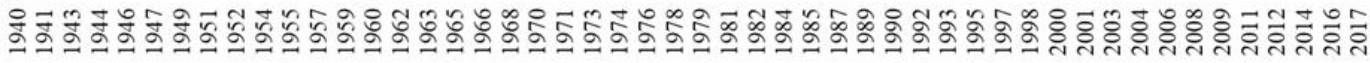

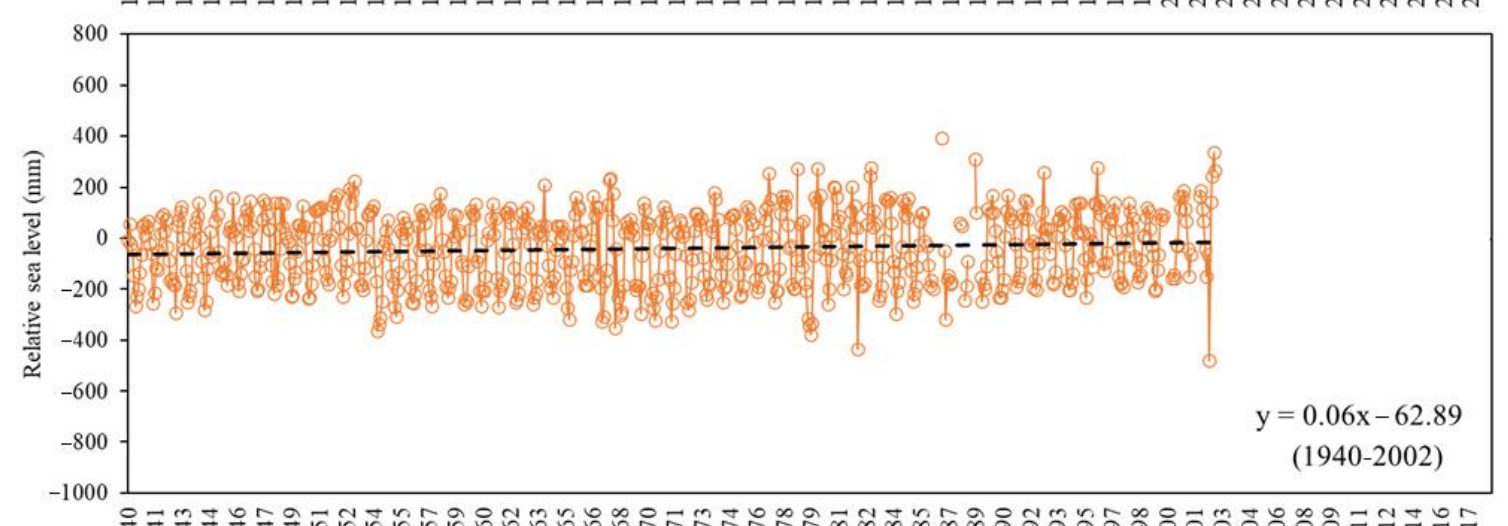

(b)

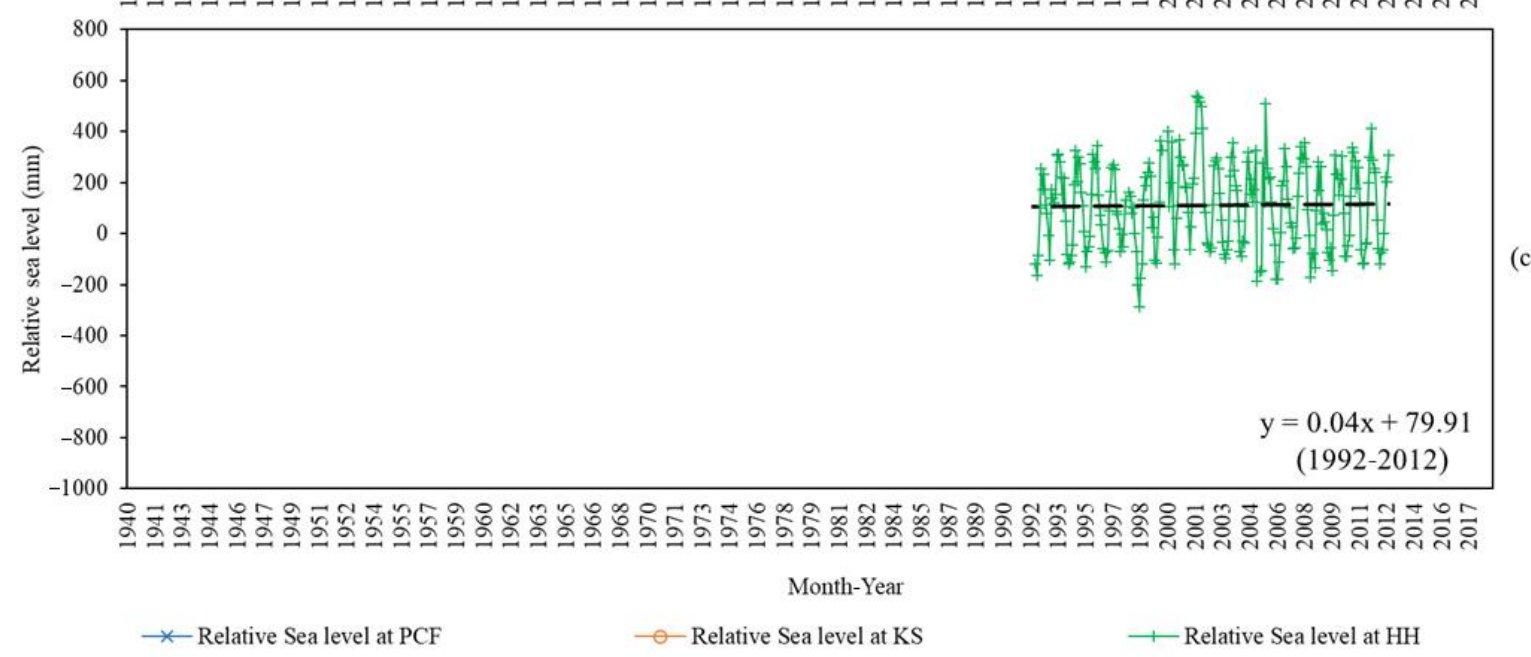

(c)

Figure 4. Observed (relative) sea levels at the (a) PCF, (b) KS, and (c) HH stations.

The monthly sea level data were available for $35 \mathrm{GCMs}$ from CMIP5. The present study has made use of all 35 CMIP5 GCMs (for r1i1p1 ensemble member) by 18 modeling centers. The data were accessed through the Earth System Grid Federation (ESGF) website [23]. The data periods include historical runs from 1976 to 2005 and future runs from 2006 to 2100 under medium- (RCP4.5) and high-emission (RCP8.5) scenarios. Table 2 provides further details of the GCMs used in the study. 
Table 2. Details of the 35 GCMs used in the study.

\begin{tabular}{|c|c|c|c|c|}
\hline Model & Modeling Center & $\begin{array}{l}\text { Atmospheric (AGCM) } \\
\text { Grid Resolution }\end{array}$ & $\begin{array}{l}\text { Oceanic (OGCM) } \\
\text { Grid Resolution }\end{array}$ & Vintage \\
\hline ACCESS1.0 & CSIRO-BOM, Australia & $192 \times 145 \mathrm{~L} 38$ & $360 \times 300 \mathrm{~L} 50$ & 2011 \\
\hline ACCESS1.3 & CSIRO-BOM, Australia & $192 \times 145 \mathrm{~L} 38$ & $360 \times 300 \mathrm{~L} 50$ & 2011 \\
\hline BCC-CSM1.1 & BCC, China & $128 \times 64 \mathrm{~L} 26$ & $360 \times 232 \mathrm{~L} 40$ & 2011 \\
\hline BCC-CSM1.1(m) & BCC, China & $320 \times 160 \mathrm{~L} 26$ & $360 \times 232 \mathrm{~L} 40$ & 2011 \\
\hline CanESM2 & CCCma, Canada & $128 \times 64 \mathrm{~L} 35$ & $256 \times 192 \mathrm{~L} 40$ & 2010 \\
\hline CCSM4 & NCAR, USA & $288 \times 192 \mathrm{~L} 26$ & $320 \times 384 \mathrm{~L} 60$ & 2010 \\
\hline CESM1(BGC) & NCAR, USA & $288 \times 192 \mathrm{~L} 26$ & $320 \times 384 \mathrm{~L} 60$ & 2010 \\
\hline CESM1(CAM5) & NCAR, USA & $288 \times 192 \mathrm{~L} 26$ & $320 \times 384 \mathrm{~L} 60$ & 2010 \\
\hline CMCC-CM & CMCC, Italy & $480 \times 240 \mathrm{~L} 31$ & $182 \times 149 \mathrm{~L} 31$ & 2009 \\
\hline CMCC-CMS & CMCC, Italy & $192 \times 96 \mathrm{~L} 95$ & $182 \times 149 \mathrm{~L} 31$ & 2009 \\
\hline CNRM-CM5 & CNRM-CERFACS, France & $256 \times 128 \mathrm{~L} 31$ & $362 \times 292 \mathrm{~L} 42$ & 2010 \\
\hline CSIRO-Mk3.6.0 & CSIRO-QCCCE, Australia & $192 \times 96 \mathrm{~L} 18$ & $192 \times 189 \mathrm{~L} 31$ & 2009 \\
\hline EC-EARTH & EC-Earth consortium, Netherland & $320 \times 160 \mathrm{~L} 26$ & $362 \times 292 \mathrm{~L} 30$ & 2010 \\
\hline FGOALS-g2 & LASG-IAP, China & $128 \times 60 \mathrm{~L} 26$ & $360 \times 196 \mathrm{~L} 30$ & 2011 \\
\hline FGOALS-s2 & LASG-IAP, China & $128 \times 108 \mathrm{~L} 26$ & $360 \times 196 \mathrm{~L} 30$ & 2011 \\
\hline FIO-ESM & FIO, SOA, China & $128 \times 64 \mathrm{~L} 26$ & $327 \times 300 \mathrm{~L} 40$ & 2011 \\
\hline GFDL-CM3 & NOAA GFDL, USA & $144 \times 90 \mathrm{~L} 48$ & $360 \times 200 \mathrm{~L} 50$ & 2011 \\
\hline GFDL-ESM2G & NOAA GFDL, USA & $144 \times 90 \mathrm{~L} 24$ & $360 \times 210 \mathrm{~L} 63$ & 2012 \\
\hline GFDL-ESM2M & NOAA GFDL, USA & $144 \times 90 \mathrm{~L} 24$ & $360 \times 200 \mathrm{~L} 50$ & 2011 \\
\hline GISS-E2-R & NASA GISS, USA & $144 \times 90 \mathrm{~L} 40$ & $288 \times 180 \mathrm{~L} 32$ & 2011 \\
\hline GISS-E2-R-CC & NASA GISS, USA & $144 \times 90 \mathrm{~L} 40$ & $288 \times 180 \mathrm{~L} 32$ & 2011 \\
\hline HadGEM2-CC & MOHC, UK & $192 \times 145 \mathrm{~L} 60$ & $360 \times 216 \mathrm{~L} 40$ & 2010 \\
\hline HadGEM2-ES & $\mathrm{MOHC}, \mathrm{UK}$ & $192 \times 145 \mathrm{~L} 38$ & $360 \times 216 \mathrm{~L} 40$ & 2009 \\
\hline INM-CM4 & INM, Russia & $180 \times 120 \mathrm{~L} 21$ & $360 \times 340 \mathrm{~L} 40$ & 2009 \\
\hline IPSL-CM5A-LR & IPSL, France & $96 \times 96$ L39 & $182 \times 149 \mathrm{~L} 31$ & 2009 \\
\hline IPSL-CM5A-MR & IPSL, France & $143 \times 144 \mathrm{~L} 39$ & $182 \times 149 \mathrm{~L} 31$ & 2009 \\
\hline IPSL-CM5B-LR & IPSL, France & $96 \times 96$ L39 & $182 \times 149 \mathrm{~L} 31$ & 2009 \\
\hline MIROC-ESM & MIROC, Japan & $128 \times 64 \mathrm{~L} 80$ & $256 \times 192 \mathrm{~L} 44$ & 2010 \\
\hline MIROC-ESM-CHEM & MIROC, Japan & $128 \times 64 \mathrm{~L} 80$ & $256 \times 192 \mathrm{~L} 44$ & 2010 \\
\hline MIROC5 & MIROC, Japan & $256 \times 128 \mathrm{~L} 40$ & $256 \times 224 \mathrm{~L} 50$ & 2010 \\
\hline MPI-ESM-LR & MPI-M, Germany & $192 \times 96 \mathrm{~L} 47$ & $256 \times 220 \mathrm{~L} 40$ & 2009 \\
\hline MPI-ESM-MR & MPI-M, Norway & $192 \times 96$ L95 & $802 \times 404 \mathrm{~L} 40$ & 2009 \\
\hline MRI-CGCM3 & MRI, Japan & $320 \times 160 \mathrm{~L} 48$ & $360 \times 368 \mathrm{~L} 51$ & 2011 \\
\hline NorESM1-M & NCC, Norway & $144 \times 96 \mathrm{~L} 26$ & $320 \times 384 \mathrm{~L} 53$ & 2011 \\
\hline NorESM1-ME & NCC, Norway & $144 \times 96 \mathrm{~L} 26$ & $320 \times 384 \mathrm{~L} 53$ & 2012 \\
\hline
\end{tabular}

\subsection{Methods}

The overall methodology of the present research is shown in Figure 5. The relative sea-level rise is defined as the sum of the total sea-level rise due to global warming (called absolute sea-level rise) and due to land subsidence [11]. In the absence of any land subsidence, the relative sea level observed at a tide gauge station is considered equal to absolute sea level. Land subsidence, largely caused by excessive groundwater withdrawal, is, therefore, a function of groundwater pumping. For the future, it is challenging to predict the groundwater pumping and associated land subsidence. Hence, a scenariobased approach depending on the observed land subsidence rate was used to develop plausible future land subsidence scenarios in the study area. The study then projected relative SLR at the three stations in the UGoT, considering the calculated land subsidence. 


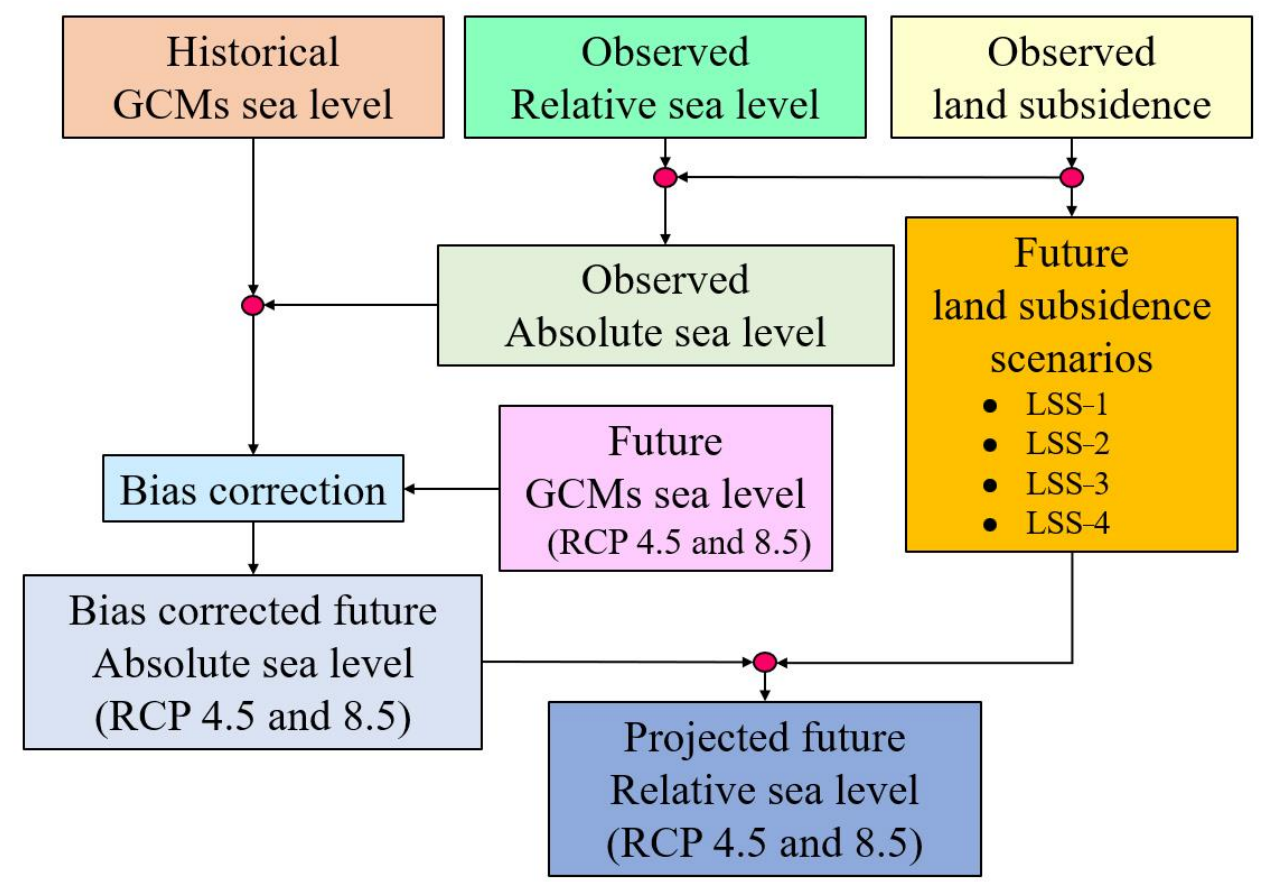

Figure 5. Flowchart of the overall methodology for the study.

\subsubsection{Observed Sea Level and Land Subsidence}

Trend analysis was performed on the relative sea-level time series data recorded at the three stations (shown in Figure 4), which would provide information not only on the rate of sea-level change but also indicate if there was any land subsidence occurring. For projecting sea-level changes in the future, it was important to quantify land subsidence in the observed sea-level change because the sea level data obtained from the climate models do not consider land subsidence. Therefore, before bias-correcting the raw GCM data, the effect of land subsidence had to be removed.

Since land subsidence records were not available at the PCF station, data at the BS station in the Samut Prakan Province-which is the nearest station to PCF (about $15 \mathrm{~km}$ ) was considered in the study. The study by Phien-wej et al. (2006) [9] reported varying rates of land subsidence in the areas surrounding the BS and PCF stations, because of which data observed at the BS station could not be used directly to eliminate the effects of land subsidence at the PCF station. In the current study, land subsidence at the PCF station was estimated iteratively by taking the percentage of land subsidence observed at the BS station in such a way that the trends of absolute sea level at the PCF and KS stations would match. It was assumed that trends in absolute sea level at the PCF and KS stations are similar, and the additional SLR trend observed at the PCF station was caused by land subsidence.

Past studies have found that groundwater-pumping-induced land subsidence has resulted in 14 and $120 \mathrm{~mm}$ /year land subsidence in Tokyo and Bangkok, respectively [9,24]. A study by Sato et al. (2006) [25] reported the importance of groundwater pumping regulations in Tokyo, where declining groundwater abstractions were slowing the rate of land subsidence. Pearson's correlation statistic suggested a strong positive relation between land subsidence and groundwater abstraction $(r=0.77)$ in the study area. Over the last 3 decades, the observed land subsidence rate and groundwater abstraction show decreasing trends (see Figure 6). Phien-wej et al. (2006) [9] also reported that regulated groundwater pumping in Bangkok has slowed down land subsidence. Hence, a constant rate of land subsidence in the future might not provide a realistic scenario. Qin et al. (2018) [26] posited various groundwater pumping scenarios using a model to control land subsidence in the Beijing plain area and found that regional land subsidence rate decreases with the reduction in the magnitude of groundwater abstraction. In the present study, future land subsidence scenarios were established assuming different rates of decrease 
in land subsidence based on the observed trends in the past 2 decades, during which groundwater pumping was regulated by the government authorities.

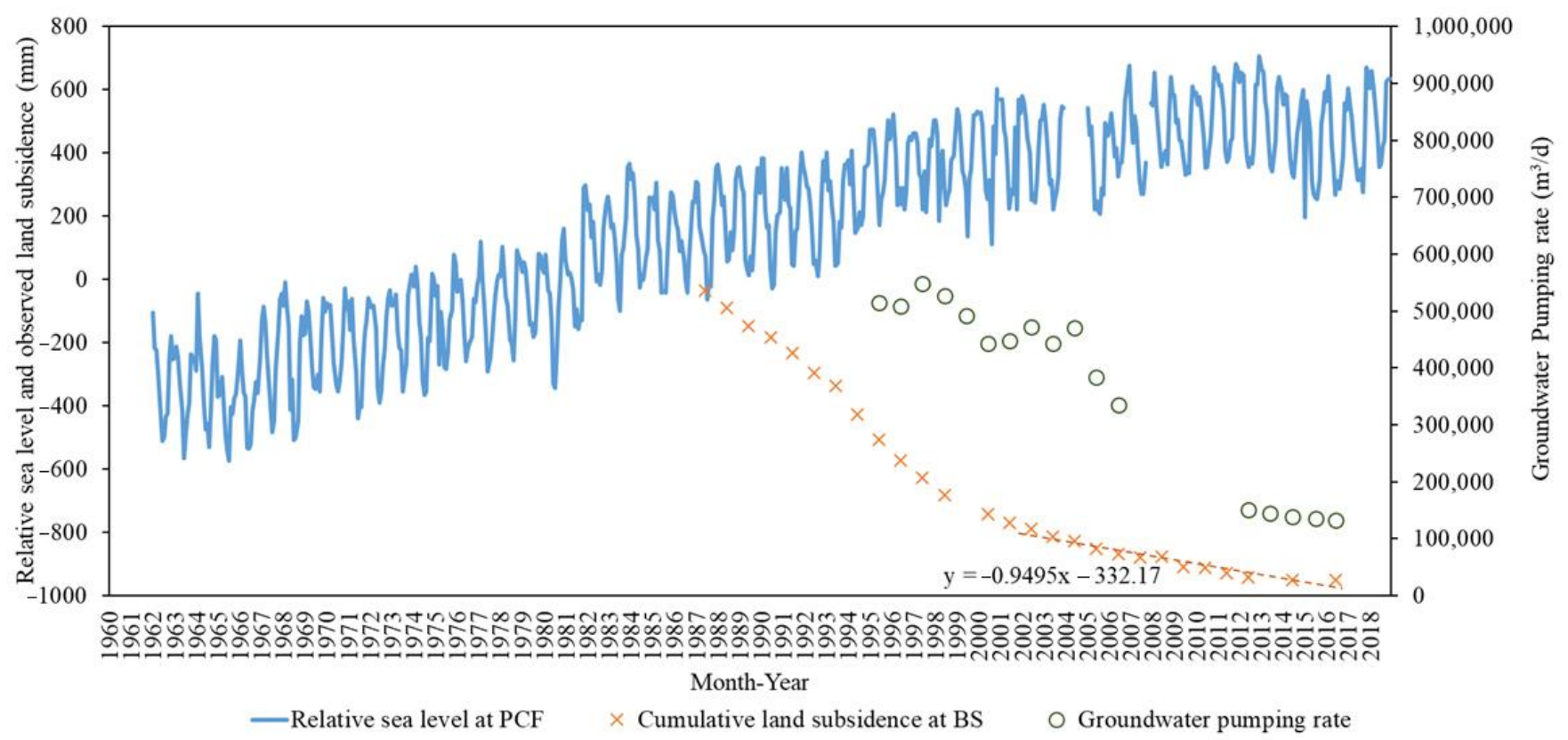

Figure 6. Observed (relative) sea level at PCF, observed land subsidence at the BS station, and the groundwater pumping rate in the Samut Prakan Province.

\subsubsection{Future Land Subsidence Scenario}

Three scenarios of future land subsidence were developed for projecting relative SLR at the PCF station based on the recent land subsidence trend (2005-2014). An overall decreasing trend of land subsidence was observed during this period, which is directly linked to the reduction in groundwater pumping in the area. It was assumed that the rate of land subsidence would decrease continuously with regulated groundwater pumping in the future. The land subsidence rate, on average, decreased by $20 \%$ each year during 2005-2014. Hence, three future scenarios of land subsidence were formulated based on an assumed 10\% (Land subsidence scenario, LSS-1), 20\% (Land subsidence scenario, LSS-2), and 30\% (Land subsidence scenario, LSS-3) annual decrease in land subsidence rate. A scenario with no land subsidence in the future (LSS-4) has also been considered in the study. The use of linear extrapolation to estimate the future land subsidence has a limitation as it may not reflect the future changes in groundwater use and the government policies for groundwater management. It is assumed that the regulatory and economic measures taken by the government since 2000 to curb excessive groundwater abstraction will continue or further strengthen in the future, resulting in a decreasing rate of land subsidence in the future.

\subsubsection{Downscaling Sea Level}

GCM data of climate and sea level are available at coarse spatial resolutions; these data need to be downscaled to a finer spatial resolution for various local applications. Biascorrection techniques are used to correct raw GCM data to remove biases in the outputs of climate models. Several methods of bias correction have been applied to correct raw GCM temperature and precipitation in several studies around the globe [27-33]. Linear Scaling (LS) [34,35], Variance Scaling (VS) [35-37], and Quantile Mapping (QM) [29,31,32] have been extensively used in bias-correcting raw climate model data on temperature and precipitation. This study compared three bias correction methods (LS, VS, and QM) for downscaling raw GCM sea level data for the baseline period (1976-2005) and applied the best method to project SLR for three future periods-near-future (2021-2050), mid-future 
(2051-2080), and far-future (2081-2100) - under RCP4.5 and RCP8.5 emission scenarios at the three stations in the UGoT. For evaluating the performance of the bias-correction methods, all 35 GCMs are considered, and their performances were assessed at the PCF station.

The LS method [34] was applied to downscale monthly raw GCM sea level data. This method operates with monthly correction values based on the differences between observed and simulated values. The following equation was used to bias-correct raw GCM sea level data:

$$
S L_{\text {cor,month }}=S L_{\text {raw }, \text { month }}+\mu\left(S L_{\text {obs,month }}\right)-\mu\left(S L_{\text {raw,monh }}\right)
$$

where $S L$ refers to the sea level, $\mu$ refers to mean value, cor refers to the corrected value, raw refers to raw data, and obs refers to observed data.

The VS method can correct both the mean and variance of time series [36]. The corrected sea level was computed using this equation:

$$
S L_{\text {cor,month }}=\left(\left[S L_{\text {raw,month }}-\mu\left(S L_{\text {raw,month }}\right)\right] \times \frac{\sigma\left(S L_{\text {obs }, \text { month }}\right)}{\sigma\left(S L_{\text {raw }, \text { month }}\right)}\right)+\mu\left(S L_{\text {obs,month }}\right)
$$

where $S L$ refers to the sea level, $\mu$ refers to mean value, $\sigma$ refers to variance, cor refers to the corrected value, raw refers to raw data, and obs refers to observed data.

QM method corrects not only the mean and variance but also the higher-order moments of the distribution [38]. The method was first introduced by Panofsky and Brier (1958) [39].

$$
S L_{(\text {cor }), \text { month }}=F_{\text {obs }}{ }^{-1}\left(F_{G C M}\left(S L_{(\text {raw }), \text { month }}\right)\right)
$$

where $S L$ refers to the sea level, cor refers to the corrected value, raw refers to raw GCM data, and $o b s$ refers to observed data. $F_{o b s}{ }^{-1}$ is the inverse cumulative distribution function corresponding to the observation and $F_{G C M}$ is the cumulative distribution function corresponding to the GCM output.

Bias-correction was applied to absolute sea level data at a monthly timescale obtained from GCMs using data for the baseline period. Four performance statistics-Mean Absolute Error $(M A E)$ (desired value of 0$)$, Coefficient of Determination $\left(R^{2}\right)$ (desired value of 1$)$, Efficiency Index or Coefficient of Efficiency (EI) (desired value of 1), and Variance (desired value which is equal to observed variance) - were used to evaluate the three bias-correction methods. Performance statistics are computed using the following equations:

Mean Absolute Error (MAE)

$$
M A E=\frac{1}{n} \sum_{i=1}^{n}\left|X_{i}-Y_{i}\right|
$$

Coefficient of Determination $\left(R^{2}\right)$

$$
R^{2}=\left(\frac{\frac{1}{n} \times \sum_{i=1}^{n}\left[\left(x_{i}-\bar{x}\right) \times\left(y_{i}-\bar{y}\right)\right]}{\sigma_{x} \times \sigma_{y}}\right)^{2}
$$

Efficiency Index $(E I)$

$$
E I=\frac{\sum_{i=1}^{n}\left(x_{i}-\bar{x}\right)^{2}-\sum_{i=1}^{n}\left(x_{i}-y_{i}\right)^{2}}{\sum_{i=1}^{n}\left(x_{i}-\bar{x}\right)^{2}}
$$

Variance (Var)

$$
\text { Var }=\frac{1}{n-1} \sum_{i=1}^{n}\left(x_{i}-\bar{x}\right)^{2}
$$

where $x_{i}$ is observed sea level for month $i, \bar{x}$ is average of observed sea level, $\mathrm{n}$ is number of data points, $y_{i}$ is simulated sea level for month $i$ by GCM, $\bar{y}$ is the average of simu- 
lated sea levels, and $\sigma_{x}$ and $\sigma_{y}$ are the standard deviation of observed and simulated sea level, respectively.

\subsubsection{Projections of Sea Level}

Using the climate change scenarios, RCP4.5 and RCP8.5, for 35 GCMs (described earlier) and the land subsidence scenarios, absolute and relative sea levels were projected for three future periods-near-future (2021-2050), mid-future (2051-2080), and far-future (2081-2100) - at three stations (PCF, KS, and HH) in the UGoT. The rate of relative SLR, as well as cumulative relative SLR, are projected until the end of the twenty-first century. It should be noted that the vertical land motion was not considered in estimating future SLR.

\section{Results and Discussion}

\subsection{Analysis of Observed Sea Level}

The observed relative SLR rate at the PCF station was approximately $1.24 \mathrm{~mm} / \mathrm{month}$ (14.88 mm/year through 1940-2018), which is relatively very high, as compared to the KS (0.72 mm/year through 1940-2002) and HH stations (0.48 mm/year through 1992 2012). The higher rate of relative SLR at the PCF station is due to land subsidence in the vicinity [16]. A closer observation of relative SLR at PCF (Figure 4a) showed three distinct trends. The period between 1941 and1960 had a relative SLR trend of $3.48 \mathrm{~mm} /$ year. During this period, groundwater abstraction was not a serious issue in the study area. However, the period between 1961 and 2000 was marked by heavy groundwater abstraction [40], which led to significant land subsidence, and hence the rate of relative SLR is the highest (21.12 mm/year) in this period. After 2000, when the effect of regulatory and economic measures, such as groundwater zoning, imposing groundwater use and conservation charges, etc. [41] to control groundwater pumping introduced in the $80 \mathrm{~s}$ and 90 s were realized, relative SLR reduced to $4.95 \mathrm{~mm} /$ year during 2001-2018 (Figure 4a). It was assumed that no land subsidence had occurred at the KS and HH stations, since the SLR trends there are very small during the observed period. Moreover, groundwater pumping in the areas surrounding these stations is not significant enough to cause land subsidence. A previous study by Vongvisessomjai (2006) [42] used data from four sea-level monitoring stations (1940-1996) and reported slightly decreasing or no trends in sea level in the GoT during the period considered. Two stations at Sattahip and Ko Lak in the Gulf of Thailand (GoT) (which are not considered in the present study), which are nearer to the UGoT, were found to have a small negative trend of $-0.36 \mathrm{~mm} /$ year in SLR. Contrary to the findings in the GoT, the absolute SLR in UGoT (at KS and HH) has slightly increasing trends (0.48-0.72 mm/year). Vongvisessomjai (2006) [42] argued that the insignificant trends of SLR in the lower latitude (including GoT) in comparison to higher latitude are due to insignificant changes in the temperature in the region.

\subsection{Groundwater Pumping and Land Subsidence}

Land subsidence has been observed in Bangkok and its vicinity (including at the PCF and BS stations) in the last 5 decades. This observed land subsidence is largely due to groundwater extraction [12]. Relative SLR at the PCF station, land subsidence observed at the BS station, and groundwater pumping rates in Samut Prakan are shown in Figure 6. As can be seen, a decreasing trend in groundwater pumping is reflected in a decreasing rate of land subsidence in recent years. This reduced rate of land subsidence can be attributed to various regulatory and economic measures taken by the Department of Groundwater Resources, Thailand, which control the use of groundwater in Bangkok and its surrounding areas $[16,43]$.

The value of absolute SLR at the KS station was used as a reference to estimate absolute SLR at the PCF station by removing land subsidence, as explained in the Methods section above. Accordingly, by trial and error, the trends of absolute SLR at PCF and KS stations were matched, and they were found to be matching when land subsidence at the PCF station was assumed to be $33.3 \%$ of that measured at the BS station. As land subsidence 
is monitored on an annual basis (Table 1), the same was interpolated on a monthly basis assuming a linear trend. Land subsidence data is available from 1987 to2016, as presented in Figure 6. It is clearly seen that there are two linear trends, one from 1987 to 1999 and the other from 2000 to 2016. Hence, for the period from 1976 to 1986, land subsidence data were linearly extrapolated using the observed data from 1987 to 1999. It is assumed that the rate of land subsidence during 1987-1999 and 1976-1986 remains the same and can be expressed by a linear equation. This assumption is considered reasonable and is supported by the observed linear trend of relative SLR at PCF from 1962 to 2000, as shown in Figure 4, which is largely due to land subsidence. The estimated and observed land subsidence at the PCF station is presented in Figure 7, which clearly shows cumulative historical land subsidence to be a major contributor to relative sea level change at this station.

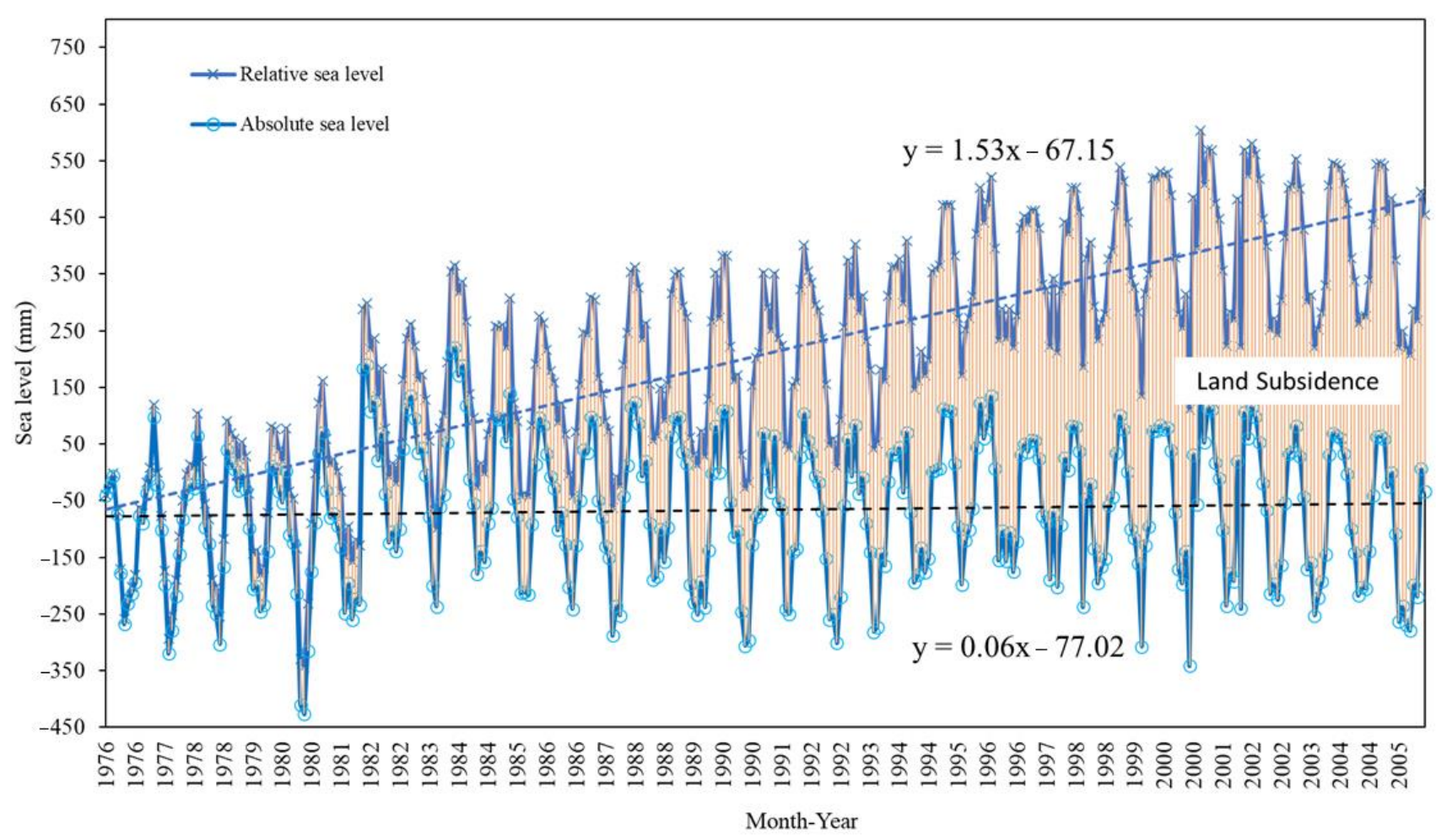

Figure 7. Relative and absolute sea levels at the PCF station. The shaded area shows estimated land subsidence over the period of 1976-2005 at the PCF.

\subsection{Future Land Subsidence Scenarios}

The estimated land subsidence rate at the PCF station from 2005 to 2012 was between 4 and $8 \mathrm{~mm} /$ year (except the year 2010). However, the rate of land subsidence decreased drastically to $1-2 \mathrm{~mm}$ /year after 2012 due to reduced groundwater pumping (Figure 6). The estimated future land subsidence scenarios at the PCF station (as described in Section 2.3.2) during the 2005-2100 period are presented in Figure 8. It can be seen that the land subsidence rate under LSS-1 will become negligible after 2070, while for LSS-2 and LSS-3, the rate will be negligible after 2040 and 2020, respectively. 


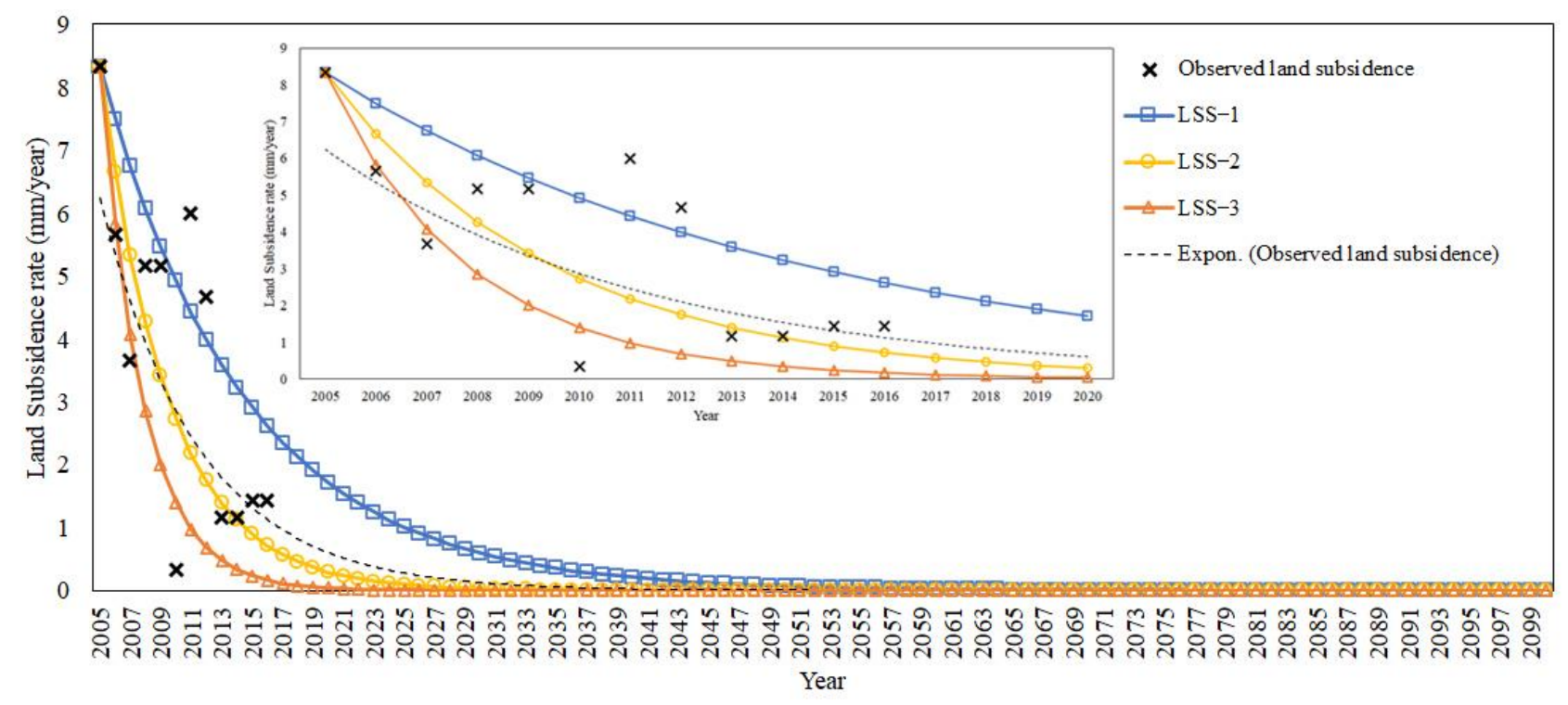

Figure 8. Observed land subsidence rate at the PCF station during the 2005-2014 period and the three formulated future land subsidence scenarios.

\subsection{Bias Correction}

Using absolute sea-level data, bias correction was carried out at the three stations (PCF, KS, HH) under consideration. The results of bias correction using the LS, VS, and QM methods for raw data from $35 \mathrm{GCMs}$ at the PCF station were evaluated and are presented in Figure 9. It shows that data corrected using the LS method were slightly better at representing the observed data compared to the VS and QM methods with a smaller value of MAE, higher values of $\mathrm{R}^{2}$, and EI. As expected, VS and QM are better at simulating the variance of the observed data. Overall, all three methods were comparable in bias correcting the raw GCM data; the results from LS were relatively better than the other two methods, and hence LS was used for bias-correcting future sea levels at the three gauging stations in the study area. 


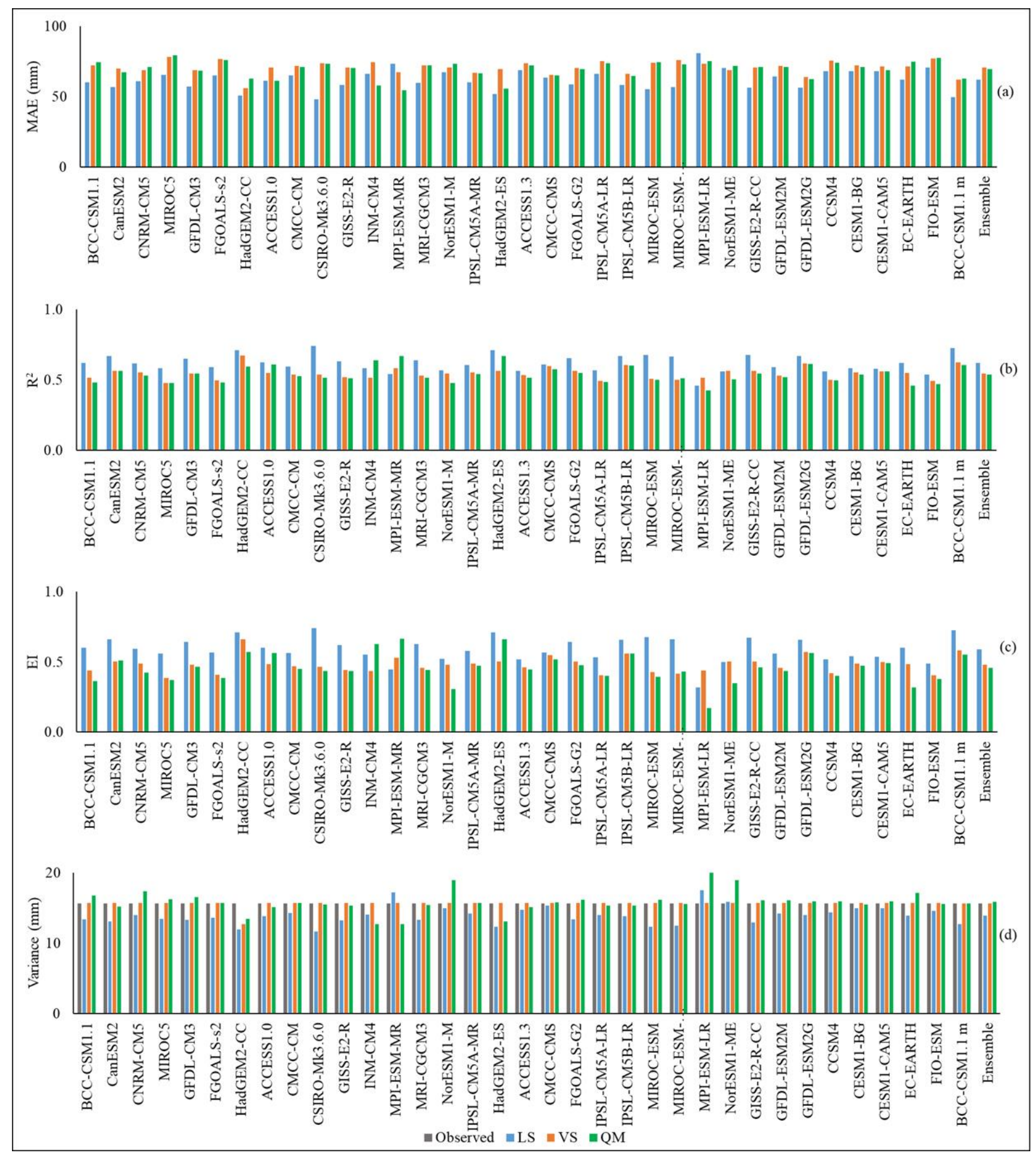

Figure 9. Performance statistics (a) Mean Absolute Error (MAE), (b) Coefficient of Determination ( $\mathrm{R}^{2}$ ), (c) Efficiency Index (EI), and (d) Variance of the three bias-correction methods (LS, VS, and QM) using historical sea-level data from 35 GCMs at the PCF station.

\subsection{Sea Level Projections}

Future relative sea levels were estimated based on the bias-corrected absolute sea levels under two climate-change scenarios and four formulated future land subsidence scenarios (at the PCF station only) for three future periods. Figure 10 presents the rate of absolute SLR for near- (2021-2050), mid- (2051-2080), and far- (2081-2100) future periods at the three stations (PCF, KS, and $\mathrm{HH}$ ). The multimodel ensemble mean suggests that projected absolute sea levels will continuously rise in the future period under both scenarios, with a 
higher rate of projected absolute SLR expected under RCP8.5 than under RCP4.5 towards the end of the twenty-first century. Model-related uncertainty under RCP4.5 was found to be the highest in the far future, as indicated by the Inter-quartile range (IQR), and the lowest during the mid-future. Under RCP8.5, uncertainty in the projection was the lowest during the near-future and the highest during the far-future. This suggests, as expected, that the uncertainty of the projection will increase with time.

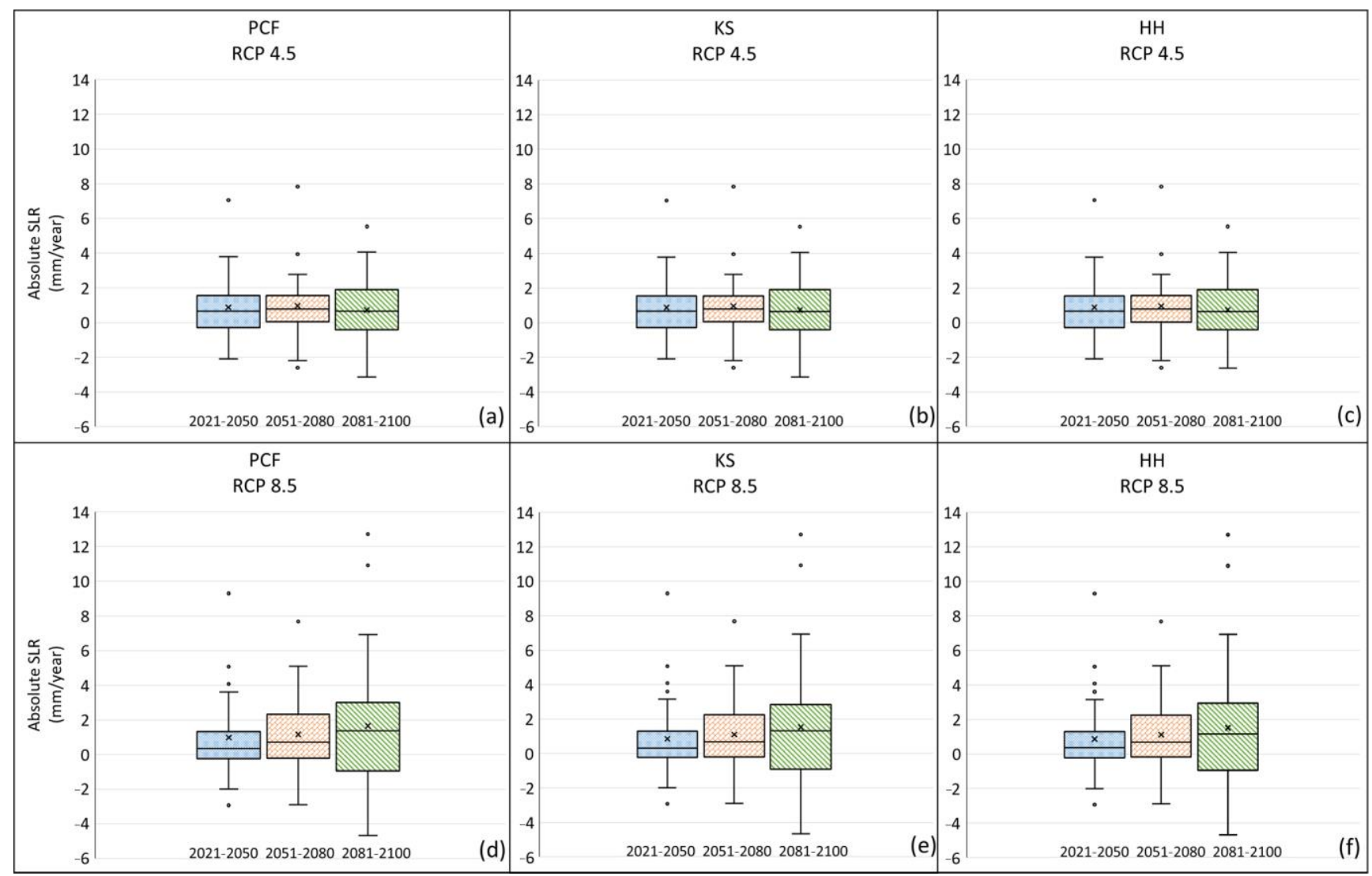

Figure 10. Boxplots depicting the projected rate of absolute SLR at three stations (PCF, KS, and HH) in the near-, mid-, and far- future periods using 35 CMIP5 GCMs. The boxes represent the interquartile range (IQR) of the rate of absolute SLR; the horizontal line in the box represents the median value; the whiskers refer to the maximum/minimum values or 1.5 times IQR. (a) at PCF under RCP4.5; (b) at KS under RCP4.5; (c) at HH under RCP4.5; (d) at PCF under RCP8.5; (e) at KS under RCP8.5; (f) at HH under RCP8.5.

In addition to climate change scenarios, land subsidence scenarios were also considered to project relative SLR in the future at the PCF station. The projected rates of relative SLR at the three stations (PCF, KS, and HH) under RCP4.5 and RCP8.5 for future periods, based on GCM ensembles mean, are presented in Table 3. If land subsidence is not considered, then the projected relative SLRs at all three stations are similar in all future periods. At PCF, the multi-model mean under RCP4.5 (and LSS-4) suggests the projected rate of relative SLR (which is equal to absolute SLR in this case) as 0.86, 0.94, and $0.71 \mathrm{~mm} /$ year for the near-, mid-, and the far-future periods, respectively. Similarly, under $\mathrm{RCP} 8.5$, the projected rates of relative SLR are $0.85,1.09$, and $1.51 \mathrm{~mm} /$ year, respectively. While for RCP4.5, the highest rates are expected during the mid-future, RCP8.5 suggests that the rate of relative SLR will be the highest in the far future. For the near-future period, not much difference was seen between the projections under RCP4.5 and RCP8.5. However, the projected rate of relative SLR is much higher under RCP8.5 in the mid- and far-future periods. With the land subsidence scenarios considered at the PCF station, the rates of relative SLR are projected to be $1.29,0.89$, and $0.86 \mathrm{~mm}$ /year for LSS-1, LSS-2, and LSS-3, respectively for the near future; and $0.96,0.94$, and $0.94 \mathrm{~mm} /$ year for the mid-future under 
the RCP4.5 scenario (Figure 11). Similarly, under RCP8.5, projected rates of relative SLR are $1.27,0.87$, and $0.85 \mathrm{~mm}$ /year in the near-future and 1.11, 1.09, and 1.09 in the mid-future under LSS-1, LSS-2, and LSS-3, respectively. In the far-future, sea-level rise will not be affected by the assumed land subsidence scenarios as the rate of land subsidence will have dropped close to zero. The highest effect of land subsidence under the assumed scenarios will be felt during the near-future period.

Table 3. The observed and projected rates of relative SLR in the UgoT using the GCM ensemble.

\begin{tabular}{|c|c|c|c|c|c|c|c|c|c|c|c|c|}
\hline \multirow{3}{*}{ Station } & \multirow{2}{*}{\multicolumn{3}{|c|}{$\begin{array}{c}\begin{array}{c}\text { Rate of Relative SLR } \\
\text { (mm/Year) }\end{array} \\
\text { Observed }\end{array}$}} & \multirow{3}{*}{$\begin{array}{c}\text { LSS } \\
\text { Scenario }\end{array}$} & \multicolumn{8}{|c|}{ Projected Rate of Relative SLR (mm/Year) } \\
\hline & & & & & \multicolumn{4}{|c|}{ RCP4.5 } & \multicolumn{4}{|c|}{ RCP8.5 } \\
\hline & $\begin{array}{c}1940- \\
2018\end{array}$ & $\begin{array}{c}1940- \\
2002\end{array}$ & $\begin{array}{c}1992- \\
2012\end{array}$ & & $\begin{array}{l}\text { Near } \\
\text { Future } \\
2021- \\
2050\end{array}$ & $\begin{array}{c}\text { Mid- } \\
\text { Future } \\
2051- \\
2080\end{array}$ & $\begin{array}{c}\text { Far } \\
\text { Future } \\
2081- \\
2100\end{array}$ & $\begin{array}{l}\text { Long- } \\
\text { Term } \\
2021- \\
2100\end{array}$ & $\begin{array}{c}\text { Near } \\
\text { Future } \\
2021- \\
2050\end{array}$ & $\begin{array}{l}\text { Mid- } \\
\text { Future } \\
2051- \\
2080\end{array}$ & $\begin{array}{c}\text { Far } \\
\text { Future } \\
\text { 2081- } \\
2100\end{array}$ & $\begin{array}{l}\text { Long- } \\
\text { Term } \\
2021- \\
2100\end{array}$ \\
\hline PCF & 14.98 & - & - & $\begin{array}{l}\text { LSS-1 } \\
\text { LSS-2 } \\
\text { LSS-3 } \\
\text { LSS-4 }\end{array}$ & $\begin{array}{l}1.29 \\
0.89 \\
0.86 \\
0.86\end{array}$ & $\begin{array}{l}0.96 \\
0.94 \\
0.94 \\
0.94\end{array}$ & $\begin{array}{l}0.71 \\
0.71 \\
0.71 \\
0.71\end{array}$ & $\begin{array}{l}1.05 \\
0.95 \\
0.94 \\
0.94\end{array}$ & $\begin{array}{l}1.27 \\
0.87 \\
0.85 \\
0.85\end{array}$ & $\begin{array}{l}1.11 \\
1.09 \\
1.09 \\
1.09\end{array}$ & $\begin{array}{l}1.51 \\
1.51 \\
1.51 \\
1.51\end{array}$ & $\begin{array}{l}1.18 \\
1.07 \\
1.07 \\
1.07\end{array}$ \\
\hline KS & - & 0.75 & - & - & 0.86 & 0.94 & 0.71 & 0.94 & 0.85 & 1.09 & 1.51 & 1.07 \\
\hline $\mathrm{HH}$ & - & - & 0.48 & - & 0.87 & 0.94 & 0.73 & 0.95 & 0.86 & 1.10 & 1.52 & 1.08 \\
\hline
\end{tabular}

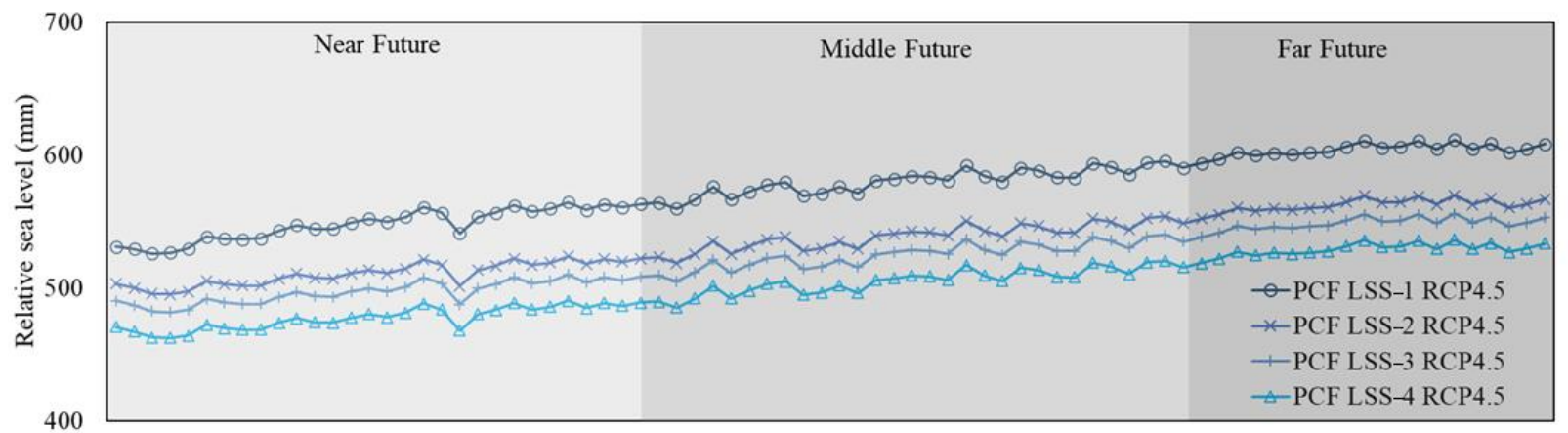

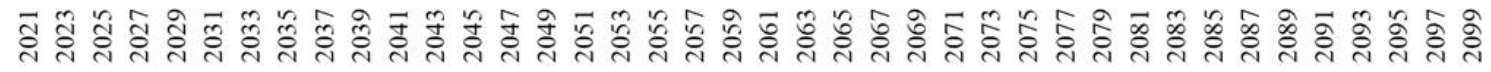

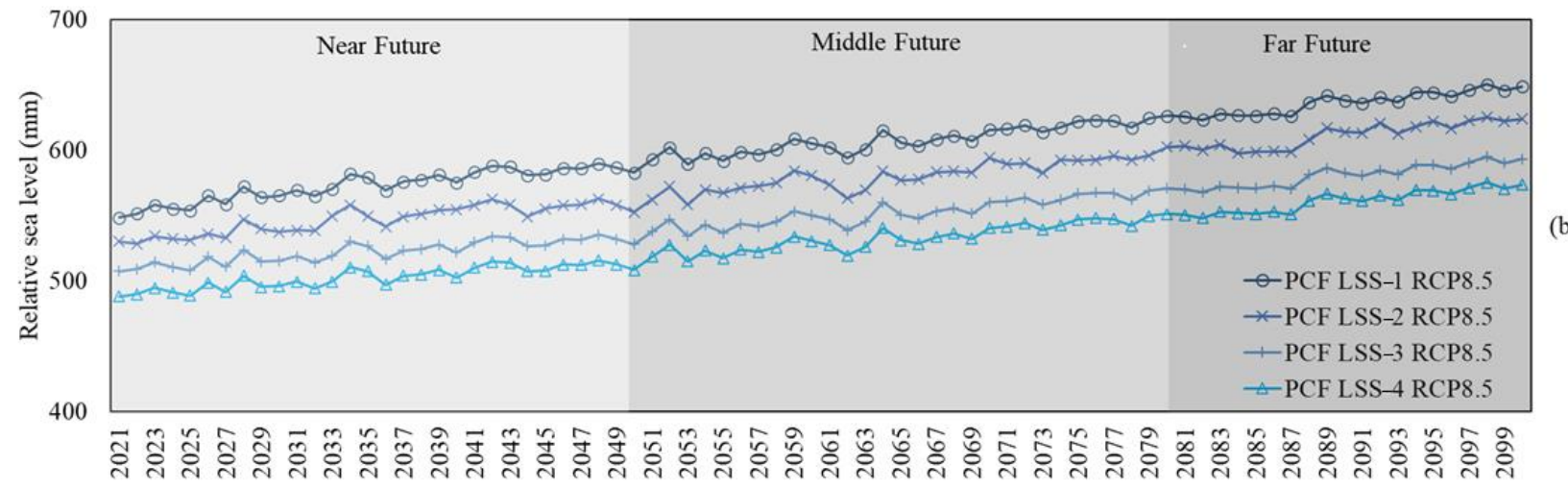

Figure 11. Future projected relative sea level (ensemble mean) for four land subsidence scenarios at the PCF station under (a) RCP4.5 and (b) RCP8.5. 
Table 4 provides the range of cumulative relative SLR for each of the three future periods under RCP4.5 and RCP8.5 obtained from 35 GCMs. It shows maximum, minimum, and ensemble-averaged projected changes in sea level for future periods. Out of the 35 GCMs used in the study, 27 GCMs project positive rates of absolute SLR in the future, while eight GCMs project negative rates of absolute SLR. The range of future projected relative sea level at three stations can also be visualized in Figure 12. Overall, in the twentyfirst century (2021-2100), at PCF, the relative sea level under RCP4.5 is projected to change between -94.70 and $616.33 \mathrm{~mm}$ if the present land subsidence trend continues (LSS-2). Similarly, at KS and $\mathrm{HH}$, the projected sea level by the climate models varies between -95.06 and $615.98 \mathrm{~mm}$ (ensemble average of $74.41 \mathrm{~mm}$ ). Under RCP8.5, the projected relative SLR during 2021-2100 at PCF is between -135.32 and $624.52 \mathrm{~mm}$ (for LSS-2) and at $\mathrm{KS}$ and $\mathrm{HH}$, between -135.65 to $624.16 \mathrm{~mm}$ (ensemble average of $84.56 \mathrm{~mm}$ ). Among the models, HadGEM2-ES, NorESM1-M, and GISS-E2-R project the highest increase in future sea levels under both scenarios, while ACCESS1.3, IPSL-CM5A-LR, and FGOALS-s2 project the highest negative changes in sea levels. If land subsidence at PCF is not considered (LSS-4), then the projected sea-level changes at all three stations are similar in all future periods. In other words, under such conditions, there is no spatial variability in sea level rise within the UGoT. Relative SLR under RCP8.5 will be higher than under RCP4.5, as suggested by the ensemble-averaged values ( $84.56 \mathrm{~mm}$ under RCP8.5 vs. $74.41 \mathrm{~mm}$ under RCP4.5 by 2100 without considering the land subsidence).

Table 4. Projected cumulative relative SLR $(\mathrm{mm})$ in the future periods in the UgoT.

\begin{tabular}{|c|c|c|c|c|c|c|c|c|c|c|}
\hline \multirow{3}{*}{ Station } & \multirow{3}{*}{$\begin{array}{c}\text { Land } \\
\text { Subsidence } \\
\text { Scenario }\end{array}$} & & \multicolumn{4}{|c|}{ RCP4.5 } & \multicolumn{4}{|c|}{ RCP8.5 } \\
\hline & & & $\begin{array}{c}2021- \\
2050\end{array}$ & $\begin{array}{c}2051- \\
2080\end{array}$ & $\begin{array}{c}2081- \\
2100\end{array}$ & 2021-2100 & $\begin{array}{c}2021- \\
2050\end{array}$ & $\begin{array}{c}2051- \\
2080\end{array}$ & $\begin{array}{c}2081- \\
2100\end{array}$ & 2021-2100 \\
\hline & & & & & & $\begin{array}{c}\text { Cumulative } \\
\text { Relative } \\
\text { SLR }\end{array}$ & & & & $\begin{array}{c}\text { Cumulative } \\
\text { Relative } \\
\text { SLR }\end{array}$ \\
\hline \multirow{12}{*}{ PCF } & \multirow{3}{*}{ LSS-1 } & $\max$ & 223.93 & 235.48 & 105.04 & 624.41 & 291.42 & 230.56 & 241.56 & 632.60 \\
\hline & & mean & 38.59 & 28.86 & 13.50 & 82.92 & 38.23 & 33.29 & 28.78 & 93.01 \\
\hline & & $\min$ & -50.51 & -77.80 & -59.98 & -86.63 & -75.42 & -86.49 & -88.79 & -127.24 \\
\hline & \multirow{3}{*}{ LSS-2 } & $\max$ & 211.91 & 234.94 & 105.02 & 616.33 & 279.41 & 230.02 & 241.54 & 624.52 \\
\hline & & mean & 26.57 & 28.32 & 13.48 & 74.83 & 26.22 & 32.75 & 28.76 & 84.91 \\
\hline & & $\min$ & -62.52 & -78.34 & -60.00 & -94.70 & -87.43 & -87.03 & -88.82 & -135.32 \\
\hline & \multirow{3}{*}{ LSS-3 } & $\max$ & 211.22 & 234.94 & 105.02 & 616.00 & 278.71 & 230.02 & 241.54 & 624.18 \\
\hline & & mean & 25.88 & 28.32 & 13.48 & 74.49 & 25.52 & 32.75 & 28.76 & 84.57 \\
\hline & & $\min$ & -63.22 & -78.34 & -60.00 & -95.04 & -88.12 & -87.03 & -88.82 & -135.65 \\
\hline & \multirow{3}{*}{ LSS-4 } & $\max$ & 211.18 & 234.94 & 105.02 & 615.98 & 278.67 & 230.02 & 241.54 & 624.16 \\
\hline & & mean & 25.84 & 28.32 & 13.48 & 74.47 & 25.48 & 32.75 & 28.76 & 84.56 \\
\hline & & $\min$ & -63.26 & -78.34 & -60.00 & -95.06 & -88.16 & -87.03 & -88.82 & -135.67 \\
\hline \multirow{3}{*}{ KS } & \multirow{3}{*}{-} & $\max$ & 211.18 & 234.94 & 105.02 & 615.98 & 278.67 & 230.02 & 241.54 & 624.16 \\
\hline & & mean & 25.90 & 28.14 & 13.48 & 74.41 & 25.44 & 32.80 & 28.78 & 84.56 \\
\hline & & $\min$ & -63.26 & -78.34 & -60.00 & -95.06 & -88.16 & -87.03 & -88.82 & -135.67 \\
\hline \multirow{3}{*}{$\mathrm{HH}$} & \multirow{3}{*}{-} & $\max$ & 211.18 & 234.94 & 105.02 & 615.98 & 278.67 & 230.02 & 241.54 & 624.16 \\
\hline & & mean & 26.00 & 28.18 & 13.84 & 74.88 & 25.71 & 32.93 & 28.94 & 84.98 \\
\hline & & $\min$ & -63.26 & -78.34 & -50.07 & -95.06 & -88.16 & -87.03 & -88.82 & -135.67 \\
\hline
\end{tabular}



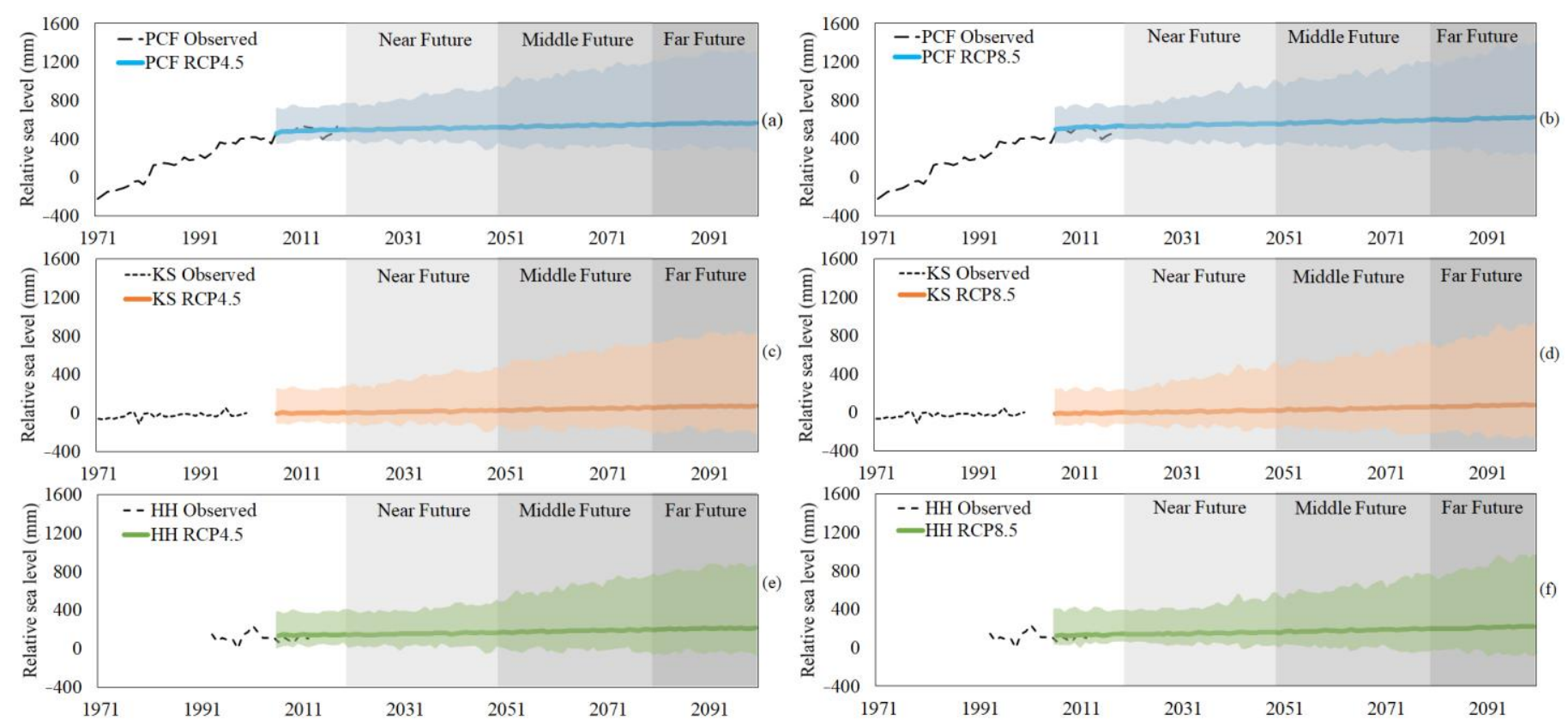

Figure 12. The observed and projected sea levels at the PCF (under LSS-2), HH, and KS stations under RCP4.5 and RCP8.5. The solid line represents the ensemble; meanwhile, the shaded area shows the range of results by 35 GCMs. (a) at PCF under RCP4.5; (b) at PCF under RCP8.5; (c) at KS under RCP4.5; (d) at KS under RCP8.5; (e) at HH under RCP4.5; (f) at HH under RCP8.5.

According to Church et al. (2013) [3], the global average rate of sea-level rise under all RCPs is very likely to exceed the observed rate of $2.0(1.7-2.3) \mathrm{mm} /$ year during 1971-2010, with the rate of rising projected to be $4-9 \mathrm{~mm}$ /year (medium confidence) under RCP4.5 and $8-16 \mathrm{~mm}$ /year (medium confidence) under RCP8.5 during 2081-2100. However, the present study found that absolute sea-level rise in the UGoT in the future will not be as severe as global average projections. Vongvisessomjai (2006) had reported that in the lower latitudes and successive humid and arid conditions, SLR would be small or even fall while SLR would be significantly larger in high and mid-latitudes, under successive glacial, interglacial, and interstadial conditions. It is interesting to note that the projected sea levels by model ensembles at PCF for the period from 2005 to 2018 are closer to the measured value, while at $\mathrm{HH}$, the projected sea level for 2006-2015 is slightly higher than the observation (Figure 11).

\section{Conclusions}

This study focused on projecting relative sea-level changes at the Phrachula Chomklao Fort (PCF) tide gauge in the UGoT considering climate change and land subsidence for the near- (2021-2050), mid- (2051-2080), and far- (2081-2100) future periods. The station is at the mouth of the Chao Phraya River, and the SLR has potential implications for municipal water supply from the river. The marked difference in relative SLR at the PCF station compared to the KS and HH stations during the observed period was found to be due to land subsidence in recent decades, which is directly linked to excessive groundwater pumping in the Samut Prakan province. We also found that the three methods of bias correction (linear scaling, variance scaling, and quantile mapping) for sea levels are comparable, although the linear scaling method performed slightly better than the other two methods. 35 GCMs used in the study show some variability in future sea-level projections, with a majority of the GCMs ( 27 out of 35 , about $80 \%$ of the models) indicating a continued increase in sea level in the twenty-first century. The results indicate that model-related uncertainties are the highest for the far-future period under both RCPs and are the least for the mid-future period under RCP4.5 and for the near-future period under RCP8.5. The overall trend of relative SLR is projected to be $0.94 \mathrm{~mm} /$ year with 
no land subsidence to $1.05 \mathrm{~mm}$ /year with maximum land subsidence under RCP4.5 and 1.07 to $1.18 \mathrm{~mm} /$ year for the corresponding land subsidence scenarios under RCP8.5 for the twenty-first century in the UGoT. Under the assumed land subsidence scenarios, the contribution of land subsidence to relative SLR in the UGoT will be relevant only in the near-future (2021-2050) period.

The analysis also reveals that future absolute SLR due to climate change in the UGoT will not be as severe as global averaged projections. However, land subsidence could still play a significant role in the near-future SLR, particularly near the Bangkok Metropolitan, as indicated by its contribution to relative SLR in recent decades. It is important to regulate groundwater abstraction in the future so that SLR can also be restricted. Such measures will be helpful not only in limiting urban flooding and coastal erosions but also in controlling salinity intrusion. In the case of the UGoT, this is even more relevant as the raw water intake from the Chao Phraya River for municipal water supply to Bangkok is close to the estuary, and relative SLR in the future can pose additional challenges in terms of salinity of raw water for the MWA. The results of the present study are being used to further investigate the effects of future relative SLR on salinity intrusion in the Chao Phraya and the associated implications and solutions for municipal water supply in Bangkok and its vicinity.

Author Contributions: Conceptualization, C.J., M.S.B., and S.S.; Data curation, C.J.; Formal analysis, C.J.; Methodology, C.J. and M.S.B.; Supervision, M.S.B., S.S., S.W., and V.N.; Validation, D.K.; WritingOriginal draft, C.J. and D.K.; Writing-Review and editing, M.S.B. All authors have read and agreed to the published version of the manuscript.

Funding: This research received no external funding.

Institutional Review Board Statement: Not applicable.

Informed Consent Statement: Not applicable.

Data Availability Statement: The data presented in this study are available on request from the corresponding author. The data are not publicly available due to privacy restrictions.

Acknowledgments: This research was part of the Ph.D. study by the first author and was funded by the Metropolitan Waterworks Authority (MWA) of Thailand and the Asian Institute of Technology (AIT), Thailand. The authors also acknowledge the support provided by the Exceed-SWINDON project of DAAD for the student-exchange program of the first author at TU-Braunschweig, Germany. The authors would like to thank the Hydrographic Department of the Royal Thai Navy, the Marine Department, the Department of Groundwater Resources, the Port Authority of Thailand, and the Permanent Service for Mean Sea Level (PSMSL) in the UK for providing the data used in this work. We would also like to thank the anonymous reviewers and the editorial team.

Conflicts of Interest: The authors declare no conflict of interest.

\section{References}

1. IPCC. Summary for Policymakers. In Global Warming of $1.5^{\circ}$ C. An IPCC Special Report; Delmotte, M., Zhai, P., Pörtner, H.-O., Roberts, D., Skea, J., Shukla, P.R., Pirani, A., Moufouma-Okia, W., Péan, C., Pidcock, R., et al., Eds.; World Meteorological Organization: Geneva, Switzerland, 2018; p. 32.

2. IPCC. Summary for Policymakers. In Climate Change 2013: The Physical Science Basis. Contribution of Working Group I to the Fifth Assessment Report of the Intergovernmental Panel on Climate Change; Stocker, T.F., Qin, D., Plattner, G.-K., Tignor, M., Allen, S.K., Boschung, J., Nauels, A., Xia, Y., Bex, V., Midgley, P.M., Eds.; Cambridge University Press: Cambridge, UK, 2013 ; p. 1535.

3. Church, J.A.; White, N.J. A 20th century acceleration in global sea-level rise. Geophys. Res. Lett. 2006, 33. [CrossRef]

4. Dangendorf, S.; Hay, C.; Calafat, F.M.; Marcos, M.; Piecuch, C.G.; Berk, K.; Jensen, J. Persistent acceleration in global sea-level rise since the 1960s. Nat. Clim. Chang. 2019, 9, 705-710. [CrossRef]

5. Hong, B.; Shen, J. Responses of estuarine salinity and transport processes to potential future sea-level rise in the Chesapeake Bay. Estuar. Coast. Shelf Sci. 2012, 104, 33-45. [CrossRef]

6. Huang, W.; Foo, S. Neural network modeling of salinity variation in Apalachicola River. Water Res. 2002, 36, 356-362. [CrossRef]

7. Bhuiyan, M.J.A.N.; Dutta, D. Assessing impacts of sea level rise on river salinity in the Gorai river network, Bangladesh. Estuar. Coast. Shelf Sci. 2012, 96, 219-227. [CrossRef] 
8. Suen, J.-P.; Lai, H.-N. A salinity projection model for determining impacts of climate change on river ecosystems in Taiwan. J. Hydrol. 2013, 493, 124-131. [CrossRef]

9. Phien-wej, N.; Giao, P.; Nutalaya, N. Land subsidence in Bangkok, Thailand. Eng. Geol. 2006, 82, 187-201. [CrossRef]

10. Ferguson, G.; Gleeson, T. Vulnerability of coastal aquifers to groundwater use and climate change. Nat. Clim. Chang. 2012, 2, 342-345. [CrossRef]

11. Liu, Y.; Li, J.; Fasullo, J.; Galloway, D.L. Land subsidence contributions to relative sea level rise at tide gauge Galveston Pier 21, Texas. Sci. Rep. 2020, 10, 17905. [CrossRef] [PubMed]

12. Saramul, S.; Ezer, T. Spatial variations of sea level along the coast of Thailand: Impacts of extreme land subsidence, earthquakes and the seasonal monsoon. Glob. Planet. Chang. 2014, 122, 70-81. [CrossRef]

13. Nerem, R.S.; Beckley, B.D.; Fasullo, J.T.; Hamlington, B.D.; Masters, D.; Mitchum, G.T. Climate-change-driven accelerated sea-level rise detected in the altimeter era. Proc. Natl. Acad. Sci. USA 2018, 115, 2022-2025. [CrossRef] [PubMed]

14. Slangen, A.B.A.; Carson, M.; Katsman, C.A.; van de Wal, R.S.W.; Köhl, A.; Vermeersen, L.L.A.; Stammer, D. Projecting twenty-first century regional sea-level changes. Clim. Chang. 2014, 124, 317-332. [CrossRef]

15. Tessler, Z.D.; Vörösmarty, C.J.; Overeem, I.; Syvitski, J.P.M. A model of water and sediment balance as determinants of relative sea level rise in contemporary and future deltas. Geomorphology 2018, 305, 209-220. [CrossRef]

16. Lorphensri, O.; Ladawadee, A.; Dhammasarn, S. Review of Groundwater Management and Land Subsidence in Bangkok, Thailand. In Groundwater and Subsurface Environments: Human Impacts in Asian Coastal Cities; Taniguchi, M., Ed.; Springer: Tokyo, Japan, 2011; pp. 127-142, ISBN 978-443-153-903-2.

17. Minderhoud, P.S.J.; Erkens, G.; Pham, V.H.; Bui, V.T.; Erban, L.; Kooi, H.; Stouthamer, E. Impacts of 25 years of groundwater extraction on subsidence in the Mekong delta, Vietnam. Environ. Res. Lett. 2017, 12, 064006. [CrossRef] [PubMed]

18. Trisirisatayawong, I.; Naeije, M.; Simons, W.; Fenoglio-Marc, L. Sea level change in the Gulf of Thailand from GPS-corrected tide gauge data and multi-satellite altimetry. Glob. Planet. Chang. 2011, 76, 137-151. [CrossRef]

19. Kulp, S.A.; Strauss, B.H. New elevation data triple estimates of global vulnerability to sea-level rise and coastal flooding. Nat. Commun. 2019, 10, 4844. [CrossRef]

20. Buranapratheprat, A.; Luadnakrob, P.; Yanagi, T.; Morimoto, A.; Qiao, F. The modification of water column conditions in the Gulf of Thailand by the influences of the South China Sea and monsoonal winds. Cont. Shelf Res. 2016, 118, 100-110. [CrossRef]

21. Suwanlertcharoen, T.; Prukpitikul, S. Detection of Phytoplankton Blooms in the Upper Gulf of Thailand Using Sentinel-3A OLCI Imagery. Environ. Nat. Resour. J. 2018, 16, 9-20. [CrossRef]

22. Yu, X.; Guo, X.; Morimoto, A.; Buranapratheprat, A. Simulation of river plume behaviors in a tropical region: Case study of the Upper Gulf of Thailand. Cont. Shelf Res. 2018, 153, 16-29. [CrossRef]

23. ESGF Node at DKRZ. Available online: https:/ / esgf-data.dkrz.de/projects/esgf-dkrz/ (accessed on 22 October 2020).

24. Hayashi, T.; Tokunaga, T.; Aichi, M.; Shimada, J.; Taniguchi, M. Effects of human activities and urbanization on groundwater environments: An example from the aquifer system of Tokyo and the surrounding area. Sci. Total Environ. 2009, 407, 3165-3172. [CrossRef] [PubMed]

25. Sato, C.; Haga, M.; Nishino, J. Land subsidence and groundwater management in Tokyo. Intern. Rev. Environ. Strateg. 2006, 6, 403-424.

26. Qin, H.; Andrews, C.B.; Tian, F.; Cao, G.; Luo, Y.; Liu, J.; Zheng, C. Groundwater-pumping optimization for land-subsidence control in Beijing plain, China. Hydrogeol. J. 2018, 26, 1061-1081. [CrossRef]

27. Piani, C.; Haerter, J.O.; Coppola, E. Statistical bias correction for daily precipitation in regional climate models over Europe. Theor. Appl. Climatol. 2010, 99, 187-192. [CrossRef]

28. Mahmood, R.; Jia, S. An extended linear scaling method for downscaling temperature and its implication in the Jhelum River basin, Pakistan, and India, using CMIP5 GCMs. Theor. Appl. Climatol. 2017, 130, 725-734. [CrossRef]

29. Maurer, E.P.; Pierce, D.W. Bias correction can modify climate model simulated precipitation changes without adverse effect on the ensemble mean. Hydrol. Earth Syst. Sci. 2014, 18, 915-925. [CrossRef]

30. Nguyen, H.; Mehrotra, R.; Sharma, A. Can the variability in precipitation simulations across GCMs be reduced through sensible bias correction? Clim. Dyn. 2017, 49, 3257-3275. [CrossRef]

31. Prasanna, V. Statistical bias correction method applied on CMIP5 datasets over the Indian region during the summer monsoon season for climate change applications. Theor. Appl. Climatol. 2018, 131, 471-488. [CrossRef]

32. Um, M.-J.; Kim, H.; Heo, J.-H. Hybrid approach in statistical bias correction of projected precipitation for the frequency analysis of extreme events. Adv. Water Resour. 2016, 94, 278-290. [CrossRef]

33. Nahar, J.; Johnson, F.; Sharma, A. Assessing the extent of non-stationary biases in GCMs. J. Hydrol. 2017, 549, 148-162. [CrossRef]

34. Lenderink, G.; Buishand, A.; van Deursen, W. Estimates of future discharges of the river Rhine using two scenario methodologies: Direct versus delta approach. Hydrol. Earth Syst. Sci. 2007, 11, 1145-1159. [CrossRef]

35. Fang, G.H.; Yang, J.; Chen, Y.N.; Zammit, C. Comparing bias correction methods in downscaling meteorological variables for a hydrologic impact study in an arid area in China. Hydrol. Earth Syst. Sci. 2015, 19, 2547-2559. [CrossRef]

36. Teutschbein, C.; Seibert, J. Bias correction of regional climate model simulations for hydrological climate-change impact studies: Review and evaluation of different methods. J. Hydrol. 2012, 456-457, 12-29. [CrossRef]

37. Terink, W.; Hurkmans, R.T.W.L.; Torfs, P.J.J.F.; Uijlenhoet, R. Evaluation of a bias correction method applied to downscaled precipitation and temperature reanalysis data for the Rhine basin. Hydrol. Earth Syst. Sci. 2010, 14, 687-703. [CrossRef] 
38. Themeß1, M.J.; Gobiet, A.; Leuprecht, A. Empirical-statistical downscaling and error correction of daily precipitation from regional climate models. Int. J. Climatol. 2011, 31, 1530-1544. [CrossRef]

39. Panofsky, H.A.; Brier, G.W. Some Applications of Statistics to Meteorology.; The Pennsylvania State University Press: Philadelphia, PA, USA, 1958.

40. Babel, M.S.; Gupta, A.D.; Sto. Domingo, N.D. Groundwater Resource Management in Bangkok. In Sustainable Groundwater Management in Asian Cities: A Summary Report of Research on Sustainable Water Management in Asia; Institute for Global Environmental Strategies: Kanagawa, Japan, 2006; pp. 71-80. Available online: http:/ /www.jstor.org/stable/resrep00865.19 (accessed on 30 April 2021).

41. Babel, M.S.; Rivas, A.A.; Gupta, A.D.; Kataoka, Y. Improving Groundwater Quality Management for the Sustainable Utilization of the Bangkok Aquifer System. Int. J. Water Resour. Dev. 2012, 28, 355-371. [CrossRef]

42. Vongvisessomjai, S. Will sea-level really fall in the Gulf of Thailand? Songklanakarin J. Sci. Technol. 2006, 28, 227-248.

43. Babel, M.S.; Gupta, A.D.; Sto. Domingo, N.D. Land subsidence: A consequence of groundwater exploitation in Bangkok, Thailand. Int. Rev. Environ. Strateg. 2006, 6, 307-328. 